\title{
Karbonátos konkréciók az alsó-miocén Pétervásárai Homokkó Formációban (Pétervásárai-dombság, Leleszi-völgy): genetikai megfontolások morfológiai és petrográfiai vizsgálatok eredményei alapján
}

\author{
Veres ZSOLT ${ }^{1 *}$, VARGA ANDREA $^{2}$ \\ ${ }^{1}$ BSZC Vásárhelyi Pál Szakgimnáziuma és Kollégiuma, 5600 Békéscsaba, Deák u. 6. \\ ${ }^{2}$ SZTE TTIK Ásványtani, Geokémiai és Kőzettani Tanszék, 6722 Szeged, Egyetem utca 2. \\ *levelező szerző: vereszsolti@gmail.com
}

Carbonate concretions in the Lower Miocene Pétervására Sandstone Formation (Pétervására Hills, Lelesz Valley): genetic considerations based on morphological and petrographic investigations

Abstract

Rocks of the shallow marine Lower Miocene Pétervására Sandstone Formation outcrop in spectacular forms in Northern Hungary. Origin of the typical carbonate concretions together with the mechanism of sandstone cementation is, however, still under debate. In this paper, selected outcrops of the Pétervására Sandstone (Pétervására Hills, Lelesz Valley) are studied using field observations and petrographic investigations. Based on our results, isolated (spherical and ellipsoidal) and stratabound concretions as well as continuously cemented layers were equally developed. In the isolated concretions grown in very coarse grained sandstones, bioclasts (e.g. shell fragments, benthic foraminifers) of different sizes and shapes were observed. Consequently, the primary source of the calcite cement could be the large amount of the detrital bioclast material (aragonite/calcite) in the studied formation. Related to the cementation processes, early crystallisation of the calcite cement started around a nucleus concentrically and the diagenetic redistribution of carbonate phases could take place during burial by diffusion. Cementation and growth mechanisms of the concretions could be significantly affected by petrological characteristics of the sediments (e.g. sorting, grain-size distribution, permeability) and by the spatial distribution of nuclei. Additionally, based on the microtextural features, the significant amount of glauconite-like grains in the Pétervására Sandstone are dominantly detrital in origin and could form earlier in the intragranular pores of the redeposited bioclast.

Keywords: Pétervására Sandstone Formation, carbonate concretion, petrography, calcite cement, bioclast, Early Miocene

Összefoglalás

Az alsó-miocén Pétervásárai Homokkő Formáció sekélytengeri képződményei Észak-Magyarországon látványos formakincset alkotva bukkannak a felszínre. A jellegzetes karbonátkonkréciók genetikája, valamint a homokkő karbonátos cementációjának részletei azonban nem ismertek megnyugtató módon. Munkánkban a képződmény felszíni kibukkanásait vizsgáltuk (Pétervásárai-dombság, Leleszi-völgy térsége), amely során a terepi megfigyeléseinket petrográfiai vizsgálatokkal egészítettük ki. Eredményeink alapján izolált (szferoidális, ellipszoidális) és rétegmenti konkréciók, valamint folyamatosan cementált rétegek egyaránt kialakultak. Az izolált konkréciókat alkotó durvaszemcsés homokkövekben különféle méretú és alakú bioklasztokat (héjtöredékek, bentosz foraminiferák) figyeltünk meg. Ez alapján a kalcitcement elsődleges ionforrása döntően az üledékbe beágyazódó, már a lerakódáskor jelenlévő bioklaszt vázelemek anyaga (aragonit/kalcit) lehetett. A cementáció a homokkőben található nukleációs pontok (pl. bioklaszt vázelemek, karbonátos kőzettörmelék-szemcsék) körül kezdődött meg koncentrikusan, diffúziós geokémiai folyamatok által vezérelve. E folyamatot az üledék kőzettani jellemzői (pl. szemcseméret, osztályozottság, permeabilitás) és a nukleuszok eloszlása jelentősen befolyásolhatta. A mikroszöveti bélyegek alapján a homokkőben feldúsuló glaukonitszemcsék legnagyobb része allotigén eredetûnek tekinthető, amelyek a karbonátos anyagú élőlények vázelemüregeiben képződtek, s a héjakkal együtt halmozódtak át.

Kulcsszavak: Pétervásárai Homokkó Formáció, karbonátos konkréció, petrográfia, kalcitcement, bioklaszt, kora-miocén

\section{Bevezetés, elózmények}

A földtani szakirodalomban BALOGH (1991) szerint a konkréciók az agyagos, homokos és meszes kőzetek finom eloszlású ásványi anyagainak egy-egy kiválási központ kö- rüli ránövekedésével (akkréciójával) létrejött, kerekded vagy a rétegzés irányában ellapult (szferoidális, ellipszoidális, korongszerú vagy szabálytalan) testek. A konkréciók csoportosítására többféle lehetôség kínálkozik, de a leggyakoribb osztályozások azok morfológiai bélyegeit, felépítô 
ásványait és kialakulási körülményeit veszik alapul (Sellés-Martínez 1996, Seilacher 2001, Boggs 2009). A konkréciók a befoglaló üledékeiknél tömörebbek, erőteljesebben cementáltak, porozitásuk kisebb, így ellenállóbbak a mállási folyamatokkal szemben. Felszíni körülmények között kipreparálódhatnak környezetükből, látványos és egyedi morfológiát alakítva ki a természetes feltárásokban (BALOGH 1991, SELLÉS-MARTíNEZ 1996, SzŐCS et al. 2015).

A különböző méretû, alakú és összetételú konkréciók gyakoriak az üledékes rétegsorokban. Nagyszámú előfordulásuk ellenére azonban képződési mechanizmusuk számos részlete még tisztázatlan. Elhanyagolt mivoltukat jelzi, hogy egykor a paleontológusok terepi munkájuk során pszeudofosszíliaként vagy éppen a „természet játékaiként” (,,lusus naturae”) tekintettek a konkréciókra (SEILACHER 2001 és az általa hivatkozott irodalmak). A rezervoár geológusok számára sem az elszigetelt konkréciók, hanem az üledékes összletek különböző módon cementált összefüggő kőzettesteinek részletes vizsgálata a cél, hisz ezek a fluidumok (pl. kőolaj, földgáz) migrációjának akadályai lehetnek (BJøRKUM \& WALDERHAUG 1990).
A Kárpát-medencei karbonátos konkréciók előfordulásának egy klasszikus területe Kolozsvár környéke volt (1. ábra a), az ott található „Feleki gömbkövek” kialakulásának lehetôségeivel és felhasználásával számos tanulmány foglalkozott (AJTAY 1994 és az általa hivatkozott irodalmak). Egyik lehetséges értelmezés, hogy áthalmozódott karbonátklasztok feloldódásából származott a kalcitcement, eredetük azonban még nem tisztázott megnyugtató módon. A magyarországi vizsgálatok közül — a teljesség igénye nélkül — kiemelhetők a mecseki perm törmelékes üledékes képződmények, amelyekből pedogén karbonátgumókat (Korpádi Homokkő Formáció; VARGA et al. 2012) és szeptáriás konkréciókat (Bodai Agyagkő Formáció; KonRÁD et al. 2010) egyaránt leírtak, valamint korong alakú, rétegszerúen elhelyezkedő konkréciókat is dokumentáltak (Kővágószőlősi Homokkő Formáció; KISS \& GRossz 1958). A negyedidőszaki paleotalajokban és egyéb laza üledékekben (pl. lösz) előforduló, döntően karbonátos anyagú konkréciókkal szintén több tanulmány foglalkozott (pl. HorvÁth et al. 2002, BAJNócZi et al. 2006, BARTA 2011, SÜMEGI et al. 2011).
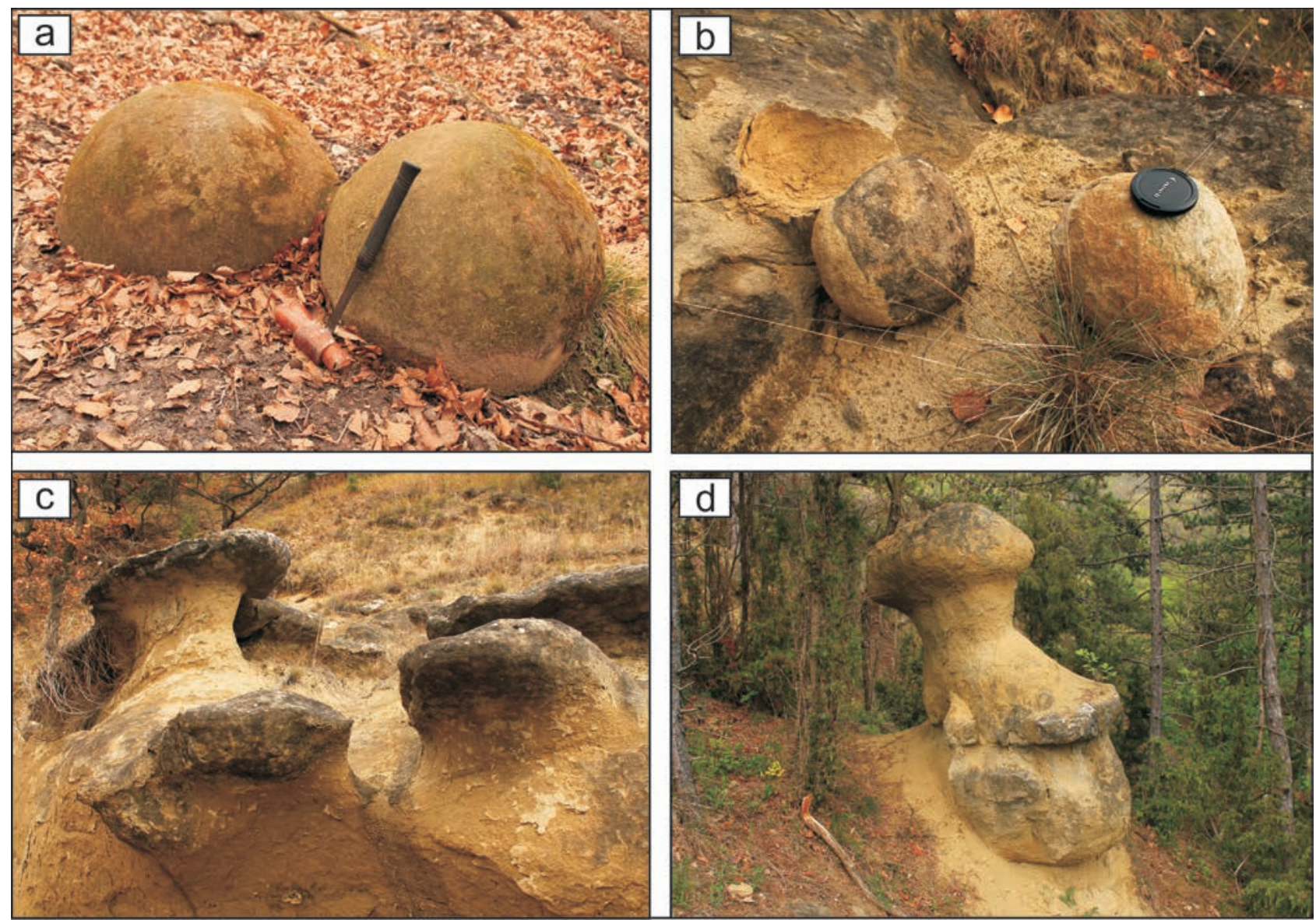

1. ábra. A karbonátos konkréciók jellemző megjelenési formái sekélytengeri homokkövekben

a) A „Feleki gömbkövek” egy természetes kibukkanása Kolozsvár mellett (Feleki-dombság, Románia); b) Izolált, szferoidális karbonátos konkréciók a bárnai Szer-kövön (Felsö-ZagyvaTarna-közi-dombság, Magyarország); c) Nem folyamatosan cementált, rétegmenti karbonátos konkréciók a bárnai Szer-kövön; d) Szelektiv denudáció által kiformált, karbonáttal cementált gombaszikla a Pes-kỏ oldalában (Pétervásárai-dombság, Magyarország)

Figure 1. Typical forms of the carbonate concretions within shallow marine sandstones.

a) A natural outcrop of the so-called "Feleki gömbkövek", natural stone balls or spheres, near Kolozsvár (Felek Hills, Romania); b) Isolated spheroidal carbonate concretions in Szer-kö, near Bárna (Felsö-Zagyva-Tarna-közi Hills, Hungary); c) Discontinuously cemented stratabound carbonate concretions in Szer-kö, near Bárna; d) Mushroom rock, a calcite-cemented natural rock formed by selective denudation (Pes-kö, Pétervására Hills, Hungary) 
Észak-Magyarországon a felszínen nagy területen fordul elô az alsó-miocén sekélytengeri Pétervásárai Homokkő Formáció. A természetes feltárások formakincsében meghatározó a szerepe azoknak az erősebben cementált egységeknek, amelyeket a mállási folyamatok preparáltak ki a kevésbé cementált kőzetrészekből (1. ábra $b-d)$. A tagolt, látványos morfológia létrejöttének megértéséhez ismernünk kell azokat a diagenetikus folyamatokat, amelyek ezek kialakításában meghatározók lehettek. Szőcs et al. (2015) megállapításai szerint a konkréciókat cementáló kalcit eredete több genetikai modellel is magyarázható a képződményben. Az elvégzett vizsgálatok alapján ugyanis nem volt egyértelmúen eldönthető, hogy ez a cementfázis az üledékkel betemetődött, tengeri eredetú pórusfluidumból és/vagy — egy későbbi folyamat eredményeként — a törések mentén a kőzettestbe jutó egzotikus fluidumból vált-e ki.

E tanulmány ennek a kérdésnek a megválaszolásához kíván további eredményeket bemutatni részben elméleti megfontolások, részben petrográfiai megfigyelések alapján. Ennek érdekében először áttekintjük a tengeri eredetú pó- rusfluidumból kiváló karbonátos konkréciók kialakulásának törvényszerúségeit és osztályozási lehetôségeit. Ezek után a konkrécióképződés szempontjából korábban kevésbé tanulmányozott észak-magyarországi mintaterületról (Pétervásárai-dombság, Leleszi-völgy; 2. ábra) származó karbonátos konkréciók üledékes kőzettani vizsgálatán keresztül vázoljuk fel a Pétervásárai Homokkőben előforduló, kalcittal cementált homokkő testek létrejöttének lehetséges körülményeit és módjait az adott területen.

\section{A karbonátos konkréciók kialakulása, morfológiája és osztályozásuk tengeri üledékképzôdési környezetre jellemzó pórusvíz mellett}

A tengeri kifejlődésú törmelékes üledékes kőzetekben a leggyakoribb konkréciók különféle karbonátásványokból épülnek fel, amelyek általában cement formájában jelennek meg a kőzetváz szemcséi között. A cementkristályok mérete

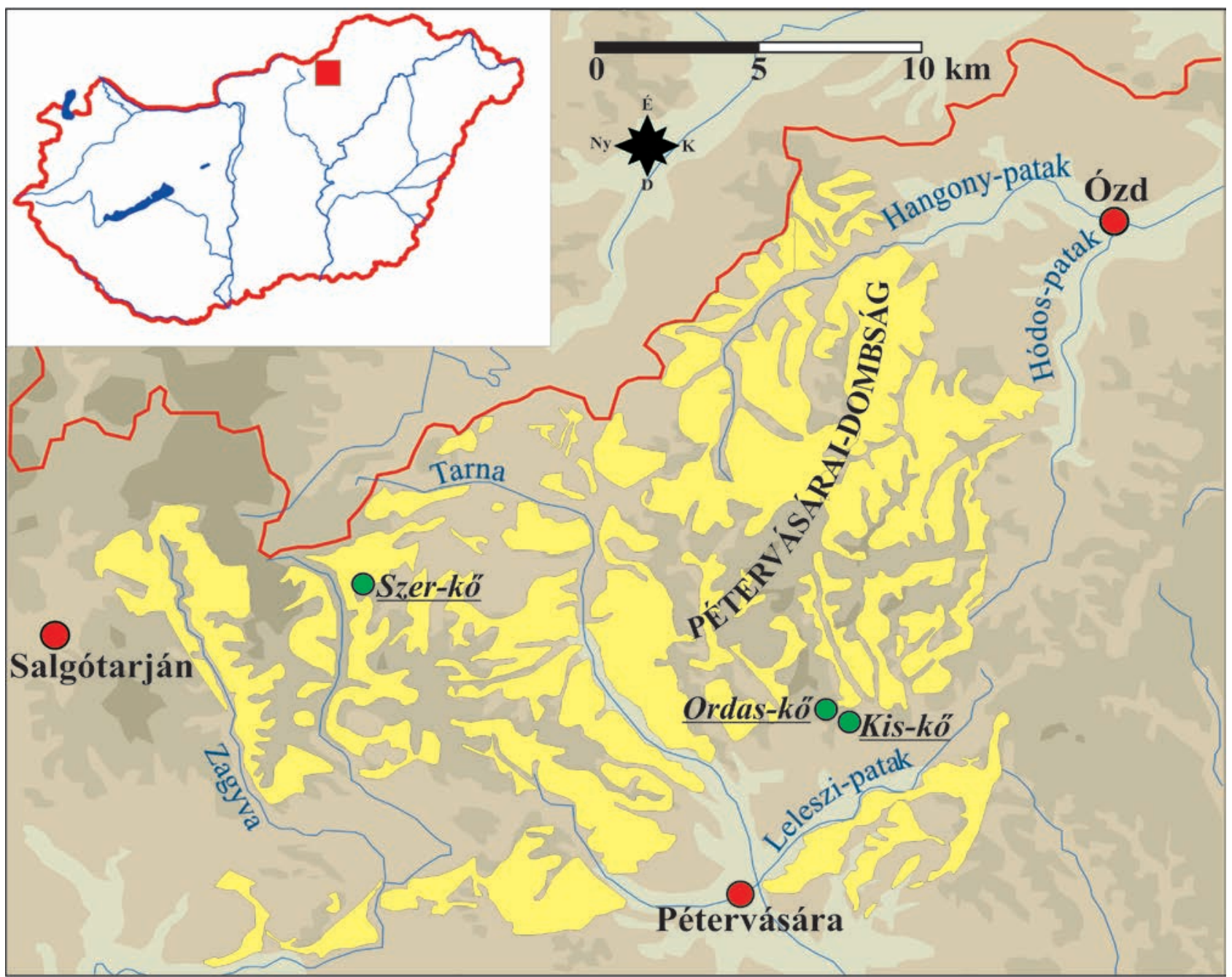

2. ábra. A Pétervásárai Homokkő egyszerủsített felszíni elterjedése és a mintavételi helyek (Kis-kő, Ordas-kő, Szer-kő) elhelyezkedése a Pétervásárai-dombság térségében

Figure 2. The generalised area with outcrops of Pétervására Sandstone and the position of the sampling sites (Kis-kö, Ordas-kö, Szer-kö, Hungarian denominations), Pétervására Hills 
a befoglaló kőzet szemcséinél többnyire kisebb. Előfordulhat azonban, hogy egy egyedi kristályszemcsék sokaságát öleli körbe (poikilotópos cement), teljesen kitöltve a kapcsolódó pórusokat (MORAD 1998, BoGGS 2009, MARSHALL \& PIRRIE 2013). A leggyakoribb cementáló karbonátásvány a kalcit $\left(\mathrm{CaCO}_{3}\right)$, de sziderit $\left(\mathrm{FeCO}_{3}\right)$ szintén előfordulhat konkréció formájában; ritka esetben ankerit $\left[\mathrm{CaFe}\left(\mathrm{CO}_{3}\right)_{2}\right]$, valamint dolomit $\left[\mathrm{CaMg}\left(\mathrm{CO}_{3}\right)_{2}\right]$ is megjelenhet. Az agyagkövekre jellemző ún. szeptáriás konkréciókban a különbözô karbonátásvány-generációk más ásványfázisokkal (pl. szulfidok: pirit, szfalerit, galenit; szulfátok: barit) váltakozhatnak (MARSHALl \& PIRRIE 2013).

A karbonátásványok alapanyaga (oldott kationok, karbonátion) belsô és külsô forrásokból egyaránt származhat (Morad 1998, Boggs 2009, Marshall \& Pirrie 2013), a következókben az ezek eredetével kapcsolatos ismereteket tekintjük át.

\section{Az oldott ionok eredete tengeri környezetben}

A víz/üledék határa alatt néhányszor 10 m-es mélységig olyan biotikus (mikrobás) folyamatok játszódhatnak le, amelyek jelentős mértékben módosíthatják a pórusvizek kémiai összetételét (3. ábra). A szerves anyag bomlásához kapcsolódó folyamatok során ugyanis a karbonátásványok kiválásához szükséges reakciótermékek szabadulnak fel (Morad 1998, Appelo \& Postma 2009, Boggs 2009, MARshall \& Pirrie 2013, YoshidA et al. 2015).

Közvetlenül a tengeraljzat közelében - általában az üledékben - húzódik az ún. oxikus zóna, ahol az oldott oxigéntartalom $0,5 \mathrm{ml} / \mathrm{l}$ feletti értékekkel jellemezhető. A zóna kiterjedése az oxigéndús tengervíz behatolási mélységétôl, valamint számos egyéb tényezôtốl (pl. üledékek szervesanyag-tartalma és lerakódási sebessége, fenékvíz oldott oxigéntartalma, bioturbáció mértéke) is függ. Az oxikus zónában előforduló vas- és mangán-oxid, -hidroxid ásványok stabilak, ezért a kialakuló karbonátos cementásványok kis vas- és mangántartalmúak (vasban szegény kalcit és dolomit), az üledékek szervesanyag-tartalma szintén elhanyagolható az oxigén jelenléte miatt (MORAD 1998, MARSHALL \& PIRRIE 2013).

Az oxikus zóna alatt helyezkedik el a szuboxikus zóna, ahol a pórusvíz oldott oxigéntartalma már $0,5 \mathrm{ml} / 1$ alatt van. Ezt a zónát további szubzónákra oszthatjuk, amelyek közül a mangán (MnR)- és a vas-redukció (FeR) övezetei a legjelentősebbek (3. ábra). Az itt kialakuló karbonátos anyagú cement típusát és kémiai összetételét nagyban meghatározza a rendelkezésre álló vas- és mangán-oxid, -hidroxid ásványok mennyisége. Ezekből az oxid- és hidroxid ásványokból nagy mennyiségú sziderit és rodokrozit jöhet létre, az $\mathrm{Fe}^{3+}$ és az $\mathrm{Mn}^{4+}$ redukciójával. Itt jegyeznénk meg, hogy a fent említett két zóna felett kialakulhat egy nitrát-redukciós szubzóna (NR), s a korábban említett szubzónákkal együtt átfedések is lehetségesek (MORAD 1998, APPELO \& POSTMA 2009, Marshall \& PirRie 2013).

A szuboxikus zóna alatt már egyáltalán nincs oldott oxigén a pórusvízben, ezért ezt az övezetet anoxikus zónának nevezzük. Ha a pórusvizek megfelelő mennyiségú oldott szulfát-anionokat $\left(\mathrm{SO}_{4}{ }^{2-}\right)$ tartalmaznak, akkor a domináns folyamat a bakteriális szulfátredukció (BSR) lesz, ahol a geokémiai folyamatokat anaerob baktériumok irányítják. A geokémiai reakciók során a pórusvíz kémhatása a lúgos irányba tolódik el, amely elősegíti a karbonátok kiválását

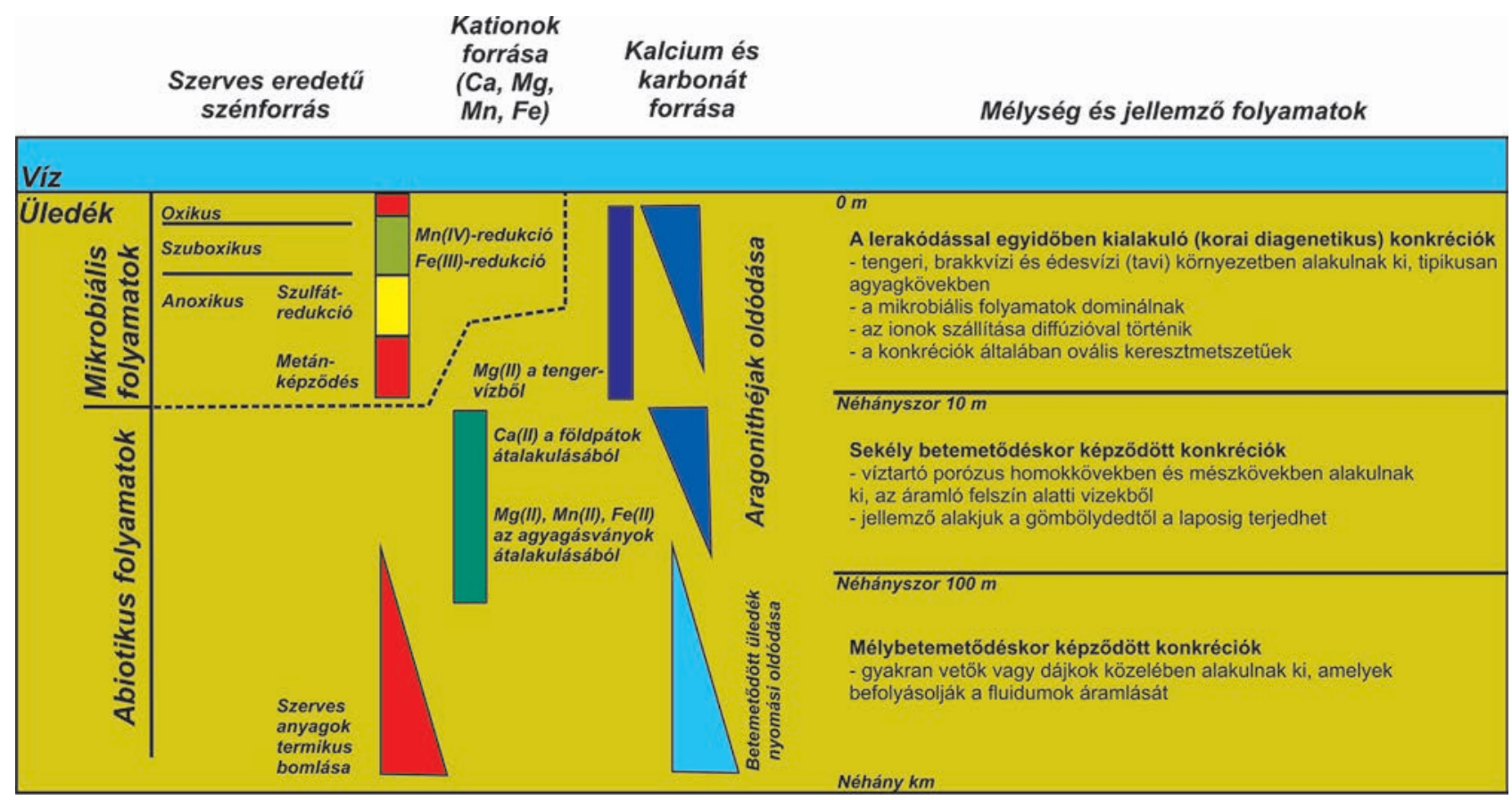

3. ábra. Az oldott ionok eredete tengeri környezetben Marshall \& PIRRIE (2013) alapján

Figure 3. Origin of dissolved ions in marine environments after MARSHALL \& PIRRIE (2013) 
ebben a zónában. A vas-szulfidok (pl. pirit, greigit) kialakulása miatt viszont vasban szegény kalcit és dolomit válhat csak ki karbonátos cementként. Az anoxikus zóna mélyebb régióiban bakteriális tevékenység által vezérelt metánképződés is zajlik (Me), ahol az oldott oxigén- és szulfáttartalom szinte teljesen hiányzik. A metánképződési folyamat egyszerú szerves vegyületek bomlásán keresztül megy végbe, a metán mellett $\mathrm{CO}_{2}$ és $\mathrm{HCO}_{3}{ }^{-}$is gazdagítja a pórusvíz kémiai összetételét (3. ábra). Az itt zajló kristályosodási folyamatok során nagy magnéziumtartalmú sziderit, nagy vastartalmú kalcit, dolomit, magnezit, valamint ankerit válhat ki. Az anoxikus zóna mikrobiális metánképzôdési övezete kb. $75^{\circ} \mathrm{C}$ hômérsékletig húzódik (az adott terület geotermikus gradiensének megfelelően). Ennél nagyobb hőmérsékleten már lelassulnak és meg is szúnnek a mikrobák által kontrollált geokémiai folyamatok. Innentôl kezdve (kb. 75-200 ${ }^{\circ} \mathrm{C}$-ig) a hőmérséklet szerepe lesz a domináns, és a legjellemzőbb ionképző folyamat a különféle szerves anyagok termikus bomlása lesz (MORAD 1998).

A karbonátásványok alkotóelemei (oldott kationok és karbonátion) belsô abiotikus forrásokból szintén származhatnak (3. ábra). Ilyen esetekben az üledékben található, olykor nagy mennyiségben jelen lévő karbonátos anyagú fosszíliák (pl. puhatestűek) vázelemei jöhetnek szóba, amelyek teljes vagy részben feloldódott maradványai mind a recens, mind pedig a fosszilis sekélytengeri üledékekben megfigyelhetôk (BJøRKUM \& WALDERHAUG 1990, WALDERHAUG \& BJøRKUM 1998). A vázelemek általában kevésbé stabil aragonitból és nagy magnéziumtartalmú kalcitból állnak (BATHURST 1975, SCHOLLE \& ULMER SCHOLLE 2003), amelyek megfelelő geokémiai környezetben feloldódhatnak, s a konkréciók alapanyagául szolgálhatnak (MARSHALL \& PIRRIE 2013). A belső karbonátforrásokat különféle kőzetek (pl. mészkő, dolomit, márvány) beágyazódó litoklasztjai is gyarapíthatják, amelyek minősége és mennyisége az üledékgyuujtő lehordási területének földtani és szállítási viszonyaitól függ. A litoklasztok karbonátásványai általában stabilabbak, nagyobb méretúek, mint a biogén vázelemek karbonátja, és fóleg kis magnéziumtartalmú kalcitból állnak (WALDERHAUG \& BJøRKUM 1998).

Szintén karbonátforrást jelenthetnek a Ca-tartalmú földpátok (pl. plagioklászok anortit komponense) és a késôbbi diagenetikus folyamatok közben (pl. nyomási oldódás), nagyobb betemetődési mélységben felszabaduló kationok és anionok is, de ezek szerepe általában másodrendú (3. ábra). A dolomit kristályrácsába beépülő magnézium származhat a tengervízből vagy különféle agyagásványok átalakulásából is, de más karbonátásványok (pl. sziderit, rodokrozit) kationjai (pl. vas, mangán) szintén származhatnak ezen átalakulási folyamatokból (MARSHALl \& PIRRIE 2013). Belsô eredetú karbonátforrások esetében az átrendeződő, azaz feloldódó, majd újra kicsapódó karbonátnak csak kisebb távolságot (cm-m) kell megtennie. A szállítás döntően diffúzió által történik, amit a helyről helyre változó kémiai koncentrációkülönbség szabályoz (BJøRKUM \& WALDERHAUG 1990).

A konkréciókat felépítő karbonátásványok ionjai nem csak a fenti biotikus és/vagy abiotikus belső forrásokból, hanem a formáción kívüli forrásokból is származhatnak. Külső források esetében a karbonátásványok alapanyaga nagyobb távolságból érkezhet (100 m - 1 km), s a szállítás itt döntôen fluidumáramlással valósulhat meg (BJøRKUM \& WALDERHAUG 1990). Ebben az esetben azonban hatalmas mennyiségú fluidum beáramlására van szükség, anyagmérleg-számítások szerint ugyanis egy pórustérfogatnyi kalcitcement kiválásához legalább 100-300 ezer pórustérfogatnyi fluidumnak kell átáramolnia egy adott póruson (BATHURST 1975, BERNER 1980, BJøRKUM \& WALDERHAUG 1990). Több sekélytengeri üledékgyújtő (pl. Norvég-tenger és Északitenger selfjei) esetében is történtek becslések arra vonatkozóan, hogy a kompakció közben felszabaduló és eláramló fluidum okozhatta-e a megfigyelt mértékú (kb. 10-30\%-os) cementációt az adott képződményt felépítő porózus kőzetben. A vizsgálatok azonban kimutatták, hogy a kalcitos cementációhoz szükséges víz kb. csak fele állhatott rendelkezésre a kompakciós folyamatok során, ezért ilyen eredetú külső karbonátforrás nem okozhatta a jelentős cementációt (BJøRKUM \& WALDERHAUG 1990). A felszínról beszivárgó meteorikus vizek már nagyobb fluidumáramlást okozhatnának, de ezeknek általában kicsi az oldott iontartalma (APPELO \& Postma 2009), továbbá a nagymérvú kalcitos cementációban való részvételüket több tanulmányban oxigénizotópos- és fluidumzárvány-vizsgálatok zárták ki (SAIGAL \& BJøRLYKKE 1987, GILES et al. 1992).

Összességében elmondhatjuk tehát, hogy van lehetőség külső karbonátforrás kialakulására, de a jelentős cementációt ezzel nem magyarázhatjuk meg, célravezetőbb a belső források feltételezése, mivel ezek általában bőségesen rendelkezésre állnak egy sekélytengeri üledékes összletben (BJøRKUM \& WALDERHAUG 1990, WALDERHAUG \& BJøRKUM 1998).

\section{Nukleáció és konkréciónövekedés tengeri környezetben}

A karbonátos konkréciók kialakulásának egyik kulcspontja a nukleációs mag (nukleusz vagy kristálygóc), amely körül a túltelített pórusvízből koncentrikusan indul meg a karbonátásványok kiválása, az ún. gócnövekedés. A folyamat hajtóereje a diffúzió, ami a koncentrációgradiensnek megfelelően folyamatosan biztosítja az anyagáramlást (APPelo \& Postma 2009, Marshall \& Pirrie 2013). A nukleuszon kikristályosodó kalcit miatt a pórusvíz karbonátkoncentrációja helyileg erôsen lecsökken, ami miatt a hatásterületen lévő karbonátforrások (pl. ôsmaradványok meszes héjai) irányából diffúziós anyagáramlás indul meg a koncentráció kiegyenlítése céljából (BJøRKUM \& WALDERHAUG 1990). A konkréciók növekedése a kezdeti, ún. átmeneti szakaszban viszonylag gyors, s az időegység alatt kikristályosodó kalcit mennyisége meghaladja a feloldódó biogén karbonátok mennyiségét a konkréció hatásterületén (BJøRKUM \& WALDERHAUG 1990, YoshidA et al. 2015). A viszonylag gyors növekedési szakasz után a konkréciónövekedés az ún. félig állandósult szakaszba lép, ahol az idôegység alatt kiváló és feloldódó karbonát mennyisége már egyenlő lesz. 
A konkréciók növekedése ebben a szakaszban már rendkívül lassú lesz, és addig tart, amíg a rendelkezésre álló karbonát el nem fogy, vagy valamely más tényező (pl. a terület kiemelkedése, egy szomszédos konkréció növekedése) ezt meg nem akadályozza (BJøRKUM \& WALDERHAUG 1990). Egy kb. 50 cm-es sugarú konkréció kialakulása néhány millió évtől akár 100 millió évig is eltarthat a formációban jelen lévő oldódóképes karbonátos szemcsék mennyiségétôl és a koncentrációgradienstől függően (BERNER 1980, BJøRKUM \& WALDERHAUG 1990, WILKINSON \& DAMPIER 1990).

A konkréciók növekedését a fent említett tényezőkön kívül a beágyazó üledékek permeabilitása is erôteljesen befolyásolja (4. ábra). Olyan sekélytengeri homokkövekben, amelyek jól osztályozottak, és amelyekben a szemcsék jól lekerekítettek, a permeabilitás minden irányban megegyező (izotróp) lesz. Megfelelô mennyiségû karbonát jelenlétében a konkréciók minden irányban egyenletesen tudnak növekedni. Ezt a homogén, rétegzetlen üledékszerkezet is elősegíti, amely kialakításában nagy szerepük lehet az aljzatban élő, bioturbációt okozó élólényeknek. Az izotróp üledékekben tehát szferoidális, gömbölyded konkréciók kialakulására lehet számítani (BJøRKUM \& WALDERHAUG 1990, MARSHALl \& PirRIE 2013).

Az agyagkövekben az agyagásvány lemezek egymással közel párhuzamos orientációja, valamint a rétegzôdés miatt az üledékek permeabilitása vízszintesen nagyobb lehet, mint függóleges irányban. A permeabilitás-anizotrópia következtében a konkréciók vízszintes tengelyük mentén megnyúltabb, lapítottabb (ellipszoidális) alakot vesznek fel (BJøRKUM \& WALDERHAUG 1990). Általánosságban elmondható, hogy a betemetôdési mélység növekedésével az anizotrópia is fokozódik, a konkréciók egyre lapítottabb alakokat hozhatnak létre (SEILACHER 2001).
A cementáltabb egységek alakját, méretét, folyamatos vagy szakaszos mivoltát a rendelkezésre álló karbonát mennyiségén kívül az üledékben található nukleuszok eloszlása is befolyásolja (4. ábra). Homogén eloszlás esetében az egymástól nagyobb távolságban lévő nukleuszok miatt önállóan és egyenletesen növekednek a konkréciók a hatásterületükrốl odaáramló és kikristályosodó karbonátásványok eredményeként. Ilyen esetben egymástól izolált konkréciók jöhetnek létre. Inhomogén nukleuszeloszlás (pl. egy rétegben, egymáshoz közel elhelyezkedő karbonátos vázelemek) és megfelelő karbonátutánpótlás esetében a növekvő konkréciók összeérhetnek, és folyamatosan cementált rétegek alakulhatnak ki. Kevesebb és egymástól távolabb elhelyezkedő nukleusz esetén (a rendelkezésre álló karbonátmennyiség elfogyása következtében) a cementált réteg nem lesz folyamatos, hanem az megszakadó formát ölthet, s ún. stratabound típusú (rétegmenti) konkréciók jöhetnek létre (BJøRKUM \& WALDERHAUG 1990).

\section{A Pétervásárai Homokkó Formáció}

Az Észak-Magyarországon, illetve Szlovákia déli részén, nagy területen (> $\left.1500 \mathrm{~km}^{2}\right)$ felszínen lévő képződmény a nannoplanktonok, továbbá a konglomerátumban található puhatestúek vizsgálati eredményei alapján eggenburgi korú (BÁLDI 1983, NAGYMAROSY \& BÁLDI-BEKE 1988). A 20-60 m tengermélységben képződött üledékes összlet uralkodóan változatos léptékben keresztrétegzett, finom-durvaszemcsés homokkő rétegek váltakozásából áll. Vastagsága - délkeletről északnyugat felé növekedve 200 és 600 m között változik (BÁLDI 1983, HÁMOR 1985, SzTANÓ 1994).

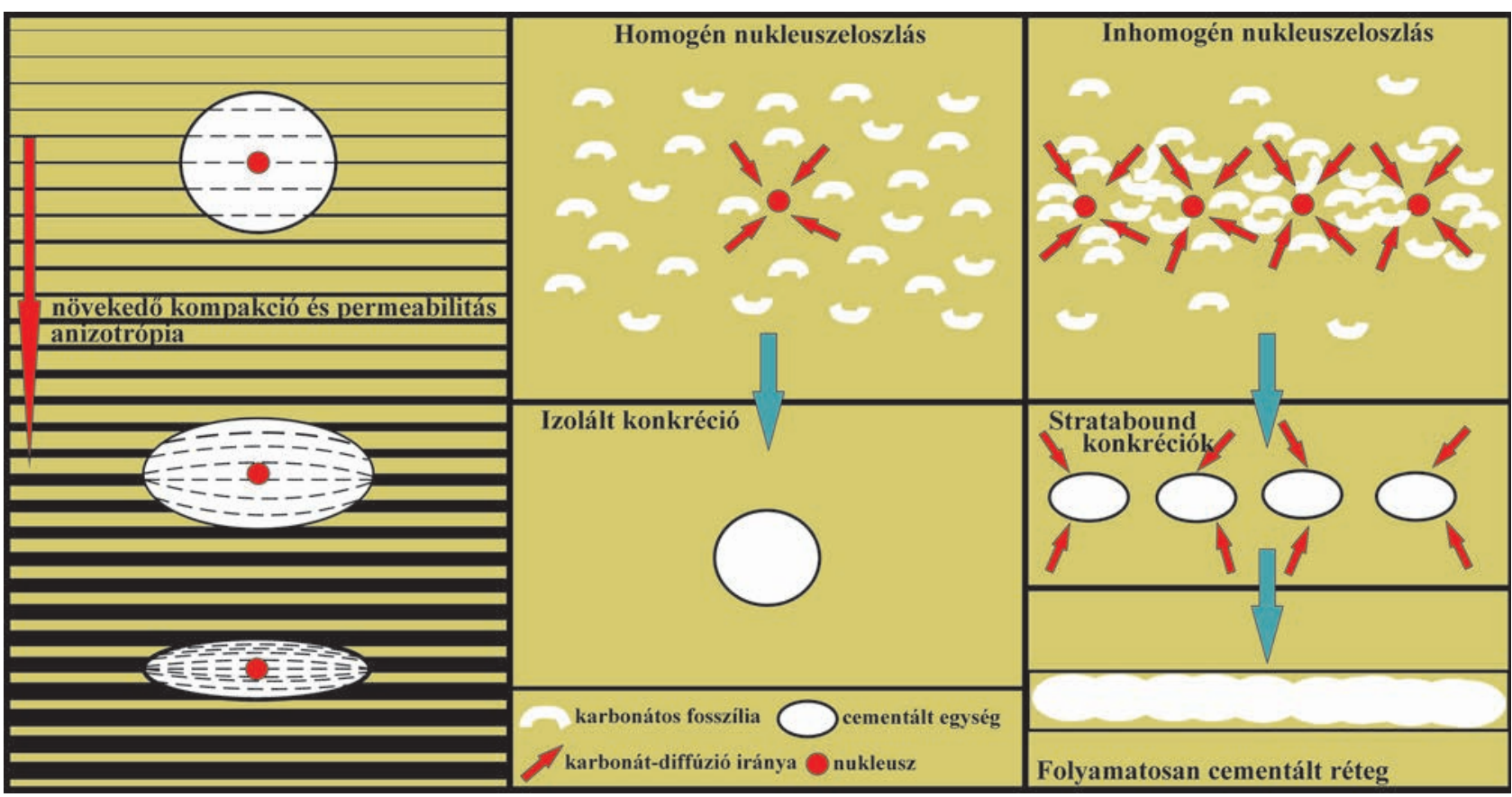

4. ábra. A karbonátos konkréciók kialakulásának lehetőségei BuørKUM \& WaLdERHAUG (1990), SEILACHER (2001) és MARSHALL \& PiRRIE (2013) alapján Figure 4. Possibilities of formation of the carbonate concretions modified after BJØRKUM \& WALDERHAUG (1990), SEILACHER (2001) and MARSHALL \& PIRRIE (2013) 
A Pétervásárai Homokkő ősmaradványokban eredendően szegény (BÁLDI 1983, 1986), ez kifejezetten igaz a formáció alsó-középsô részére, míg a felsô (Ilonavölgyi) tagozata lumasellaszerú faunát (összemosott és összetört kagylóhéjak) tartalmaz (BÁLDI 1983, FôZY \& LEÉL ŐsSY 1985). Az ősmaradványok mellett a felső szintek durvakavicsos, tufás, tufitos, bentonittörmelékes horizontokat is hordoznak. Az üledékes összletben ritkán szénült növényi maradványok töredékei figyelhetôk meg, valamint gyér foraminiferafaunát is kimutattak, de a makrofauna gyakorlatilag hiányzik (BÁLDI 1983, HÁMOR 1985).

A formációt a felszínen általában sárga, szürkésfehér vagy zöldesszürke színú, karbonátos kötőanyagú, különféle mértékben cementált homokkő alkotja, a konglomerátumbetelepülések alárendeltek (BÁLDI 1983, SzTANÓ 1994, SZTANó \& JózSA 1996, Szócs et al. 2015). A homokfrakcióban a szemcsék általában jól osztályozottak és szögletesek (HÁMOR 1985). Átlagos karbonáttartalma 14-15\%, de ez helyenként akár 25-51\% is lehet (VASS \& ELEČKO 1992). A képződmény homokfrakciójának anyaga déli irányból szállítódott, a kőzettörmelék-szemcsék között jelentős az intermedier magmás eredetű, metamorf és üledékes (pl. mészkő, homokkő) szemcsék aránya (SzTANó \& JózsA 1996, Szőcs et al. 2015). Ehhez a Darnói Konglomerátum törmelékszemcséivel azonos eredetú (triász-jura óceánaljzati bazalt, radiolarit) kavicsanyag keveredett. A Pétervásárai Homokkő kőzettani összetétele területi változást mutat: a névadó területtől északnyugat felé - a Darnó-zónától távolodva egyre csökken a vulkáni eredetû kőzettörmelék-szemcsék (beleértve az ofiolit eredetű törmeléket is) mennyisége, míg a radiolaritszemcséké növekszik (SzTANó \& JózSA 1996).

Az ásványtani vizsgálatok alapján megállapítható, hogy a homokfrakcióban a kvarc az uralkodó, de a káliföldpát, a csillámok (muszkovit, klorit, kloritosodó-glaukonitosodó biotit) és a különféle gránátok (almandin-grosszulár) is jellemzőek (HÁMOR 1985, FeKETE 2003). A formáció egyes tagozatainak jellegzetes ásványa a zöld színú vas-alumínium-hidroszilikát ásvány, a glaukonit (BÁLDI 1983), amely helyenként a kôzetnek zöldes színárnyalatot ad (a formáció régies elnevezése a „glaukonitos homokkő” volt). FEKETE (2003) ásványtani vizsgálatai alapján megállapította, hogy a Pétervásárai Homokkőben (Istenmezeje) található glaukonit színe a sötétzöld-feketétôl a világoszöldig változik. A szemcsék általában laposak, kerekre koptatottak, a felszínük sima, fényes. Alárendelten előfordulnak palásan-lemezesen szétesett szemcsék is.

A homokkő betemetődés-történetének és a porozitásfejlődésének rekonstrukciója során Szőcs et al. (2015) egy kishartyáni feltárásnál végzett vizsgálat alapján négy litofáciest különítettek el. Az általuk porózusnak elnevezett litofácies (LF1) apró- és középszemcsés, 10-30 cm vastag homokkő rétegekből áll, míg a mátrixgazdag egységek (LF2) aprószemcsés, 5-10 cm-es rétegekból, amelyek gyakran bioturbáltak. E két litofácies az egyenes és befelé hajló falszakaszokban jelenik meg. A cementgazdag egységek (LF3) 10-50 cm vastag apró- és durvaszemcsés rétegekből épülnek fel, amelyek helyenként bioturbáltak vagy kereszt- rétegzettek. Az utolsó litofácies (LF4) az előző két változat keveréke (mátrix- és cementgazdag), és pados kifejlődésú (10-30 cm), apró- és középszemcsés homokkőből áll. Az utóbbi két litofácies-típus a fal síkjából kiemelkedő szakaszokat képviseli.

A Pétervásárai Homokkővel fedett területeken szembeötlő a változatos és látványos formakincs, melynek létrejötte a homokkövek eltérō cementáltságával és az ehhez kapcsolódó mállási folyamatokkal van összefüggésben (HoRvÁTH 2007, SzŐCs et al. 2015). SzŐCs et al. (2015) szerint a homokkő lerakódását követően zajló diagenezis egy kései fázisában válhattak ki a formáció egyes részeiben azok a kalcitok, amelyek cementként és ásványhelyettesítésként épültek be a kôzetszövetbe. A homokköves összletben áramló fluidumokból a kalcit a megfelelő szemcseösszetételú, nagyobb porozitású és permeabilitású részeken vált ki. Emiatt a kalcittal jobban cementált részek a kőzettestben elszigetelt lencsékben, foltokban, sávokban alakultak ki.

A terület betemetődési modellje alapján a Pétervásárai Homokkő Formáció kb. 8 millió évvel ezelőtt érte el a maximális betemetôdési mélységét, s az elmúlt 5 millió év óta emelkedő fázisban van (BEKE \& FODOR 2015). A felszín közelébe kerülő és a homokköveken átszivárgó, csapadék eredetú (meteorikus) vizek kezdték el azt az oldási folyamatot, mely részben még ma is zajlik. A kalcittal cementált, kevésbé porózus részek útját állták az áramló fluidumoknak, míg a porózusabb részek oldása sokkal intenzívebb volt. Ennek megfelelően az oldási, mállási folyamatok kihangsúlyozták a cementációs különbségeket (szelektív denudáció), amely hatására rendkívül változatos kőzetmorfológia alakulhatott ki (SzŐCs et al. 2015).

\section{Mintagyưjjtés, vizsgálati módszerek}

A Pétervásárai Homokkő Formációban megjelenő karbonátkonkréciók vizsgálatához a Tarnalelesz közelében található Leleszi-völgyben, a Kis-kő és az Ordas-kő elnevezésú homokkő feltárásokból 16 kőzetminta begyújtésére került sor (2. ábra; I. táblázat). A terepi mintagyújtés alkalmával a kőzettest felületérôl geológus kalapáccsal távolítottuk el az egyes mintákat. Azok begyújtése során ügyeltünk arra, hogy az eltérôen cementált egységekből egyaránt rendelkezésünkre álljon minta. A mintavételi helyeken írásos és digitális terepi dokumentációt végeztünk. A dokumentáció során fontos szempont volt, hogy a begyújtött minták (pl. izolált konkréciók) milyen viszonyban állnak a környezetükkel (alak, kiterjedés, makroszkóposan megfigyelhetố szemcseméret és üledékszerkezeti jegyek, viszony a szomszédos cementált és kevésbé cementált egységekkel, felszíni mállás hatására kialakuló másodlagos bélyegek stb.). A fentieken túl dokumentáltuk az egyes mintagyújtési helyek tengerszint feletti magasságát, valamint égtáj szerinti kitettségét is. A területi változékonyság tesztelésére egy, a mintaterülettől (Leleszi-völgy) távolabb esô feltárásból (bárnai Szer-kô) is történt mintázás az ott előforduló izolált, szferoidális konkréciókból (I. táblázat). 
I. táblázat. A Kis-kőről, az Ordas-kőről és a Szer-kőről gyűjtött minták összefoglaló táblázata

Table I. General characteristics of the studied samples from the Kis-kö, Ordas-kö and Szer-kö

\begin{tabular}{|c|c|c|c|c|c|c|}
\hline $\begin{array}{l}\text { Minta } \\
\text { kódja }\end{array}$ & Minta típusa & \multicolumn{3}{|c|}{$\begin{array}{l}\text { Mintázási helyek paraméterei } \\
\text { (EOV, tszf. mag., helyszín) }\end{array}$} & \multirow{2}{*}{$\begin{array}{c}\text { Makroszkópos leirás } \\
\text { sárgásbarnás színü, ellipszis a lakú }(\mathrm{H}: 9,5 \mathrm{~cm} \text {; } \\
\text { Sz: } 7 \mathrm{~cm} ; \mathrm{M}: 4 \mathrm{~cm}), \text { a közepén jobban, a } \\
\text { szélein kevésbé cementált durvasze mcsés } \\
\text { homokkő }\end{array}$} & \multirow{2}{*}{$\begin{array}{c}\begin{array}{c}\text { Litofácies } \\
\text { típusa }\end{array} \\
\text { LF3 }\end{array}$} \\
\hline KK1 & magányos konkréció & E732663; N303978 & $340 \mathrm{~m}$ & $\begin{array}{l}\text { Kis-kő D-i alsó, } \\
\text { lankás oldala }\end{array}$ & & \\
\hline KK2 & magányos konkréció & E732663; N303978 & $340 \mathrm{~m}$ & $\begin{array}{l}\text { Kis-kö D-i alsó, } \\
\text { lankás o ldala }\end{array}$ & $\begin{array}{l}\text { szürkésbarnás színü, limonitos peremü, } \\
\text { lapitott (H: } 11 \mathrm{~cm} \text {; Sz: } 5 \mathrm{~cm} \text {; M: } 4 \mathrm{~cm}) \text {, a } \\
\text { közepén jobban cementált közép-és } \\
\text { nagyszemcsés ho mokkö }\end{array}$ & LF3 \\
\hline KK3 & $\begin{array}{l}\text { konkréciókat bezáró, } \\
\text { kevésbé cementált } \\
\text { homokkô }\end{array}$ & E732663; N303978 & $340 \mathrm{~m}$ & $\begin{array}{l}\text { Kis-kô D-i alsó, } \\
\text { lankás oldala }\end{array}$ & $\begin{array}{l}\text { sárgásb arnás színü, morzsalékos, } \\
\text { durvaszemcsés homokkő }\end{array}$ & LF1 \\
\hline KK4 & magányos konkréció & E732663; N303978 & $340 \mathrm{~m}$ & $\begin{array}{l}\text { Kis-kő D-i alsó, } \\
\text { lankás oldala }\end{array}$ & $\begin{array}{c}\text { sárgásb arnás színü, szürke foltos, lapított }(\mathrm{H} \text { : } \\
12 \mathrm{~cm} \text {; } \mathrm{Sz}: 11 \mathrm{~cm} ; \mathrm{M}: 2,5 \mathrm{~cm}) \text {, durvaszemc sés } \\
\text { homokkö }\end{array}$ & LF3 \\
\hline KK5 & $\begin{array}{l}\text { kevésbé cementált, } \\
\text { összefüggö réteg }\end{array}$ & E732844; N303845 & $361 \mathrm{~m}$ & $\begin{array}{l}\text { Kis-kö D-i felsö, } \\
\text { függőleges oldala }\end{array}$ & $\begin{array}{l}\text { sárgásb arnás színü, morzsalékos, } \\
\text { finomkavicsos durvaszemcsés homokkő }\end{array}$ & LF1 \\
\hline KK6 & $\begin{array}{l}\text { cementált, } \\
\text { összefüggö réteg }\end{array}$ & E732844; N303845 & $361 \mathrm{~m}$ & $\begin{array}{l}\text { Kis-kö D-i felsö, } \\
\text { függőleges oldala }\end{array}$ & $\begin{array}{l}\text { szürkésbarnás színü, limonittal sávozott, } \\
\text { finomkavicsos konglomerátum és } \\
\text { durvaszemesés homokkő }\end{array}$ & LF3 \\
\hline KK7 & $\begin{array}{l}\text { kevésbé cementált, } \\
\text { összefüggő réteg }\end{array}$ & E732844; N303845 & $361 \mathrm{~m}$ & $\begin{array}{l}\text { Kis-kö D-i felső, } \\
\text { függöleges oldala }\end{array}$ & $\begin{array}{c}\text { szürkésbarnás színũ, limonittal sávozott, } \\
\text { morzsalékos, szórtan finomkavicsos } \\
\text { durvaszemcsés homokkő }\end{array}$ & LF1 \\
\hline KK8 & magányos konkréció & E714066; N317947 & $360 \mathrm{~m}$ & $\begin{array}{l}\text { Kis-kõ DK-i alsó, } \\
\text { lankás oldal }\end{array}$ & $\begin{array}{l}\text { sárgásb arnás színü, limonittal sávozott, } \\
\text { lapított }(\mathrm{H}: 13 \mathrm{~cm} ; \mathrm{Sz}: 12 \mathrm{~cm} ; \mathrm{M}: 4 \mathrm{~cm}) \text {, jól } \\
\text { cementált, szórtan finomk avicsos } \\
\text { durvaszemesés homokkő }\end{array}$ & LF3 \\
\hline KK9 & magányos konkréció & E714066; N317947 & $360 \mathrm{~m}$ & $\begin{array}{l}\text { Kis-kö DK-i alsó, } \\
\text { lankás oldal }\end{array}$ & $\begin{array}{c}\text { sárgásbarnás színü, közepén szürke, lapított } \\
\text { (H: } 15 \mathrm{~cm} ; \mathrm{Sz}: 14 \mathrm{~cm} ; \mathrm{M}: 5 \mathrm{~cm}) \text {, jól } \\
\text { cementált, szórtan finomk avicsos } \\
\text { durvaszemcsés homokkö }\end{array}$ & LF3 \\
\hline KK 10 & magányos konkréció & E714066; N317947 & $360 \mathrm{~m}$ & $\begin{array}{l}\text { Kis-kő DK-i alsó, } \\
\text { lankás oldal }\end{array}$ & $\begin{array}{c}\text { sárgásbarnás színũ, lapított }(\mathrm{H}: 16 \mathrm{~cm} ; \mathrm{Sz}: 11 \\
\mathrm{cm} \text {; M: } 5 \mathrm{~cm}) \text {, jól cementált, szórtan } \\
\text { finomkavicsos durvaszemcsés homokkő }\end{array}$ & LF3 \\
\hline OK1 & magányos konkréció & E714051; N317958 & $330 \mathrm{~m}$ & $\begin{array}{l}\text { Ordas-kő DNy-i } \\
\text { alsó, lankás } \\
\text { oldala }\end{array}$ & $\begin{array}{l}\text { sárgásszürkés színü, gömbölyũ }(\mathrm{H}: 15 \mathrm{~cm} ; \mathrm{Sz} \text { : } \\
13 \mathrm{~cm} ; \mathrm{M}: 7 \mathrm{~cm}) \text {, jól cementált, } \\
\text { középszemcsés ho mokkő }\end{array}$ & LF3 \\
\hline OK2 & magányos konkréció & E714051; N317958 & $330 \mathrm{~m}$ & $\begin{array}{l}\text { Ordas-kő DNy-i } \\
\text { alsó, lankás } \\
\text { oldala }\end{array}$ & $\begin{array}{l}\text { szürkésbarnás, limonittól sávozott, gö mbölyū } \\
\text { (legnagyobb átmérō: } 21 \mathrm{~cm} \text {; M: } 4 \mathrm{~cm} \text { ), jól } \\
\text { cementált, közép-és nagyszemc sés homokkő }\end{array}$ & LF3 \\
\hline OK3 & magányos konkréció & E714051; N317958 & $330 \mathrm{~m}$ & $\begin{array}{l}\text { Ordas-kô DNy-i } \\
\text { alsó, lankás } \\
\text { oldala }\end{array}$ & $\begin{array}{l}\text { sárgásbarnás színü, ellipszis alakú }(\mathrm{H}: 9 \mathrm{~cm} \text {; } \\
\text { Sz: 7,5 cm; M: } 4 \mathrm{~cm}) \text {, a közepén jobban, a } \\
\text { szélein kevésbé ce mentált, közép- és } \\
\text { nagyszemcsés ho mokkö }\end{array}$ & LF3 \\
\hline OK4 & magányos konkréció & E714051; N317958 & $330 \mathrm{~m}$ & $\begin{array}{l}\text { Ordas-kő DNy-i } \\
\text { alsó, lankás } \\
\text { oldala }\end{array}$ & $\begin{array}{l}\text { sárgásb arnás (koncentrikus) színü, ovális } \\
\text { alakú }(\mathrm{H}: 22 \mathrm{~cm} ; \mathrm{Sz} \text { : } 14 \mathrm{~cm} \text {; M: } 5 \mathrm{~cm}) \text {, jól } \\
\text { cementált, közép-és nagyszemc sés homokkő }\end{array}$ & LF3 \\
\hline $0 \mathrm{~K} 5$ & $\begin{array}{l}\text { konkréciókat bezáró, } \\
\text { kevésbé cementált } \\
\text { homokkő }\end{array}$ & E714051; N317958 & $330 \mathrm{~m}$ & $\begin{array}{l}\text { Ordas-kö DNy-i } \\
\text { alsó, lankás } \\
\text { oldala }\end{array}$ & $\begin{array}{c}\text { sárgásb arnás színü, morzsalékos, közép- és } \\
\text { nagyszemcsés ho mokkö }\end{array}$ & LF1 \\
\hline 0K6 & magányos konkréció & E714051; N317958 & $330 \mathrm{~m}$ & $\begin{array}{l}\text { Ordas-kố DNy-i } \\
\text { alsó, lankás } \\
\text { oldala }\end{array}$ & $\begin{array}{l}\text { sárgásb arnás színũ, ovális alakú (H: } 25 \mathrm{~cm} \text {; } \\
\text { Sz: } 23 \mathrm{~cm} \text {; M: } 13 \mathrm{~cm}) \text {, jól cementált, közép- } \\
\text { és nagyszemcsés homokkő }\end{array}$ & LF3 \\
\hline SZK 1 & magányos konkréció & E716173; N306595 & $390 \mathrm{~m}$ & $\begin{array}{l}\text { Szer-kô DNy-i } \\
\text { alsó, lankás } \\
\text { oldala }\end{array}$ & $\begin{array}{l}\text { sárgásbarna szinü, közel gömb alakú (H: } 12 \\
\text { cm; Sz: } 11 \mathrm{~cm} ; \mathrm{M}: 10 \mathrm{~cm}) \text {, jól cementált, } \\
\text { finom- és aprószemc sés homokkö }\end{array}$ & LF3 \\
\hline
\end{tabular}

Rövidítések: H=hosszúság; Sz=szélesség; M=magasság. Litofácies típusa: Szőcs et al. (2015) által használt litofácies típusok kódjai: LF1=porózus litofácies LF3=cementgazdag litofácies.

Abbreviations: H=length; Sz=width; M=hight. The code of lithofacies type (SzÖCS et al. 2015): LF1=porous sandstone; LF3=cement-rich sandstone. 
A terepen begyújtött kőzetmintákból a Szegedi Tudományegyetem Ásványtani, Geokémiai és Kőzettani Tanszékén összesen 15 darab vékonycsiszolat készült. A kiválasztott konkréciókat középpontjukon áthaladva kettévágtuk, majd mind a külső, mind a központi részből egy-egy kék múgyantával vákuum-impregnált, polírozott vékonycsiszolat készült. A Szer-kő́n begyújtött izolált konkréciók egyikéből öt darab csiszolatot vizsgáltunk, belülrôl kifelé haladva, cm-es bontásban. A karbonátfázis jellemzésére a vékonycsiszolatokat Na-alizarin-szulfonát és kálium-hexaciano-ferrát színezőanyagok felhasználásával festettük meg (DiCKSON 1966). E festési eljárás alkalmazásával polarizációs mikroszkópban is elkülöníthetők a vastartalmú (Fekalcit: bíbor; Fe-dolomit, ankerit: kék), ill. vasmentes (kalcit: rózsaszín/piros; dolomit: színtelen) karbonátok.

\section{Terepi megfigyelések}

Tarnalelesz községtől ÉNy-ra, a Nagy-völgyi-patak és a Mocsolyás-patak között található homokkő vonulat DDK-i irányba néző leszakadásánál található a Kis-kő (Kis-kő- tető). A 360-380 m tengerszint feletti magasságban húzódó, jelentôs vertikális és horizontális kiterjedésú homokkô fal a Pétervásárai Homokkő Formáció egyik legjobban megközelíthetô természetes földtani feltárása a területen. A növényzettől mentes, jól áttekinthető feltárásban méteres keresztrétegzettségú, kavicsos durvaszemcsés homokkő, valamint finomkavicsos konglomerátum tanulmányozható. A kibukkanás felső részén meredek falban preparálódnak ki a rétegek, míg lent a mállás miatt lankás, egyenetlen lejtôt alkotnak (5. ábra a). A kisebb mértékủ tagoltság ellenére a feltárás ezen szakasza jelentős mennyiségben tartalmaz a környezeténél jobban cementált, ezért abból kipreparálódó konkréciókat. A konkréciók döntő többsége egy viszonylag jól lehatárolható réteg mentén helyezkedik el, de nem szabályos (kb. 10-50 cm) távolságokban (5. ábra $b)$. A felületet alaposabban szemügyre véve viszont olyan kipreparálódott konkréciók is megfigyelhetôk, amelyek izoláltan helyezkednek el (5. ábra c), s makroszkóposan a felszínen nem mutatnak kapcsolatot a környező, jobban cementált egységek felé. Folyamatosan cementált rétegek a feltárás ezen részében nem figyelhetôk meg. A konkréciók nagyobb része ellipszoidális (szélesség/magasság: 7/4),
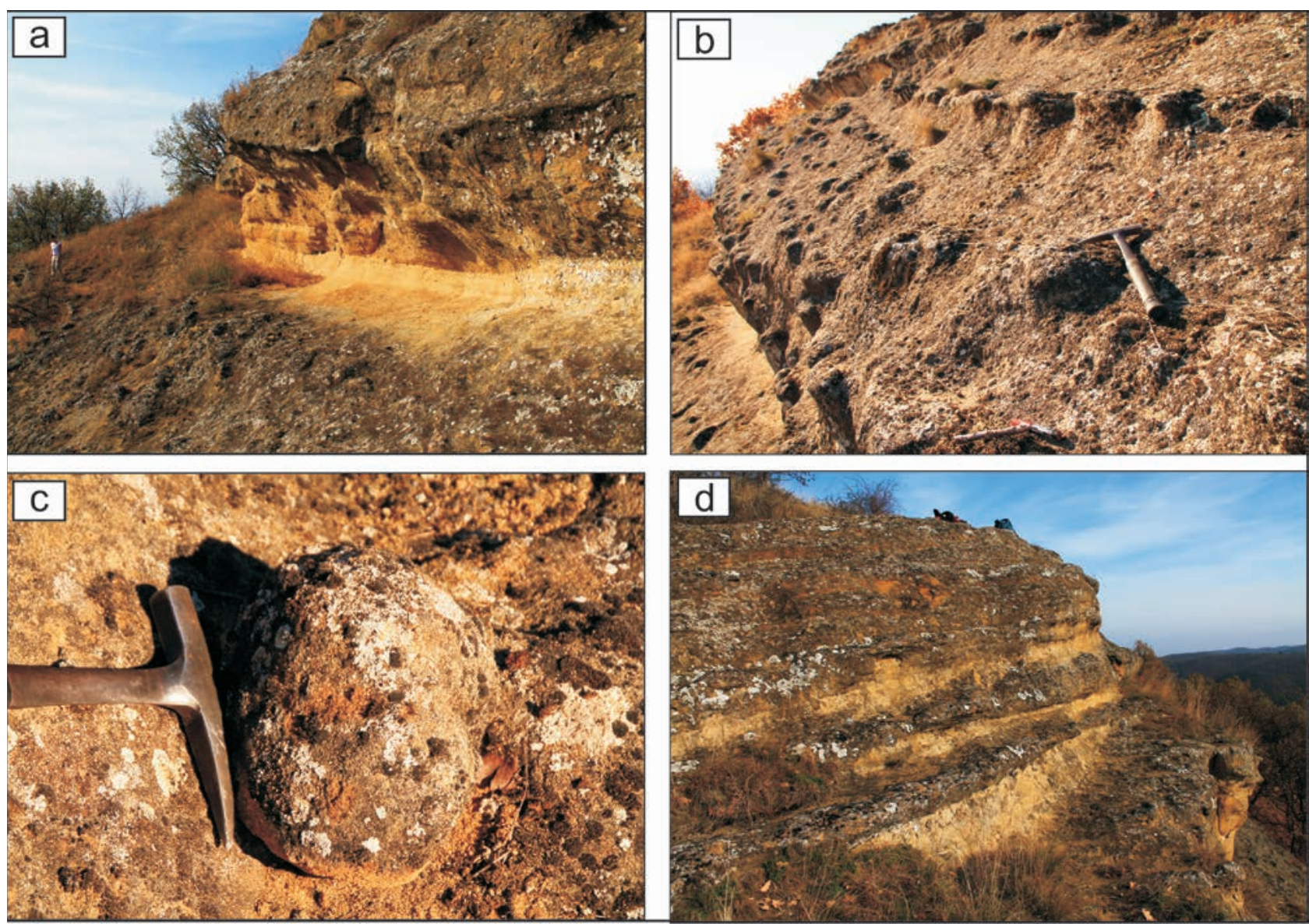

5. ábra. A Tarnalelesz mellett található Kis-kő homokkő feltárásai

a) A Kis-kő jellegzetes, kettős osztatú feltárásának távlati képe; b) Réteghez kötött konkréciók a Kis-kő K-i, felső részén; c) Izolált, szferoidális konkréció a Kis-kő K-i, alsó részén; d) Folyamatosan cementált rétegek a Kis-kő feltárásának Ny-i, felső részén

Figure 5. Natural outcrops of the Kis-kö near Tarnalelesz

a) A typical outcrop of the Kis-kö, showing two distinctive parts: stratabound concretions (b) in the upper part of the outcrop and isolated spheroidal carbonate concretions (c) in the lower part, eastern view; d) Continuously cemented lavers in the upper part of the outcrop of the Kis-kö, western view 
kisebbik hányaduk szferoidális, átlagos méretük 15-25 cm között változik.

A feltárásban felfelé haladva egy mállottabb részt követôen (Kis-kői-eresz) elérünk annak függőleges részéhez, amely már jóval tagoltabb a lentihez képest, s konkréciói is hangsúlyosabbak. A feltárás K-i részében rétegmenti konkréciók a dominánsak, amelyek szabályos (kb. 10-20cm) távolságokban követik egymást, s közülük néhány ellipszoidális konkréció pereme már össze is ér (szélesség/magasság: 8/5). A feltárás legfelső és Ny-i részében a karbonáttal cementált egységek folyamatos rétegek formájában jelennek meg, amelyek nagy részében makroszkóposan jól kivehetô, hogy azok a lapított konkréciók oldalirányú összenövésével jöttek létre (5. ábra d). A megnyúlt, ellipszoidális konkréciók átlagos mérete kb. 20-30 cm.

A Kis-kőtől ÉNy-ra, a Mocsolyás-patak völgyfője fölé magasodik a DDNy-i irányba néző Ordas-kő, ami több száz méteres hosszával a terület egyik legnagyobb természetes földtani feltárása. A markáns homokkő fal a Kis-kőhöz hasonlóan litológiai/morfológiai alapon két egységre osztható, az uralkodó szemcseméret azonban közép-nagyszemcsés. A meredek, szinte függóleges alsó szakaszon a réteg- menti konkréciók a gyakoriak, amelyek között a térközök nem szabályosak (kb. 10-50 cm). Ezek mellett az izolált konkréciók szintén gyakoriak, de a folyamatosan cementált rétegek hiányoznak (6. ábra $a, b$ ). A konkréciók alakja közel szferoidális, átlagos méretük 15-25 cm közötti. Az Ordaskő aljában fellelhetô, az aprózódási folyamatok által „félbevágott" konkréciókon több esetben körkörös (koncentrikus) sárgásbarna rajzolatok, Liesegang-gyúrúk figyelhetők meg (6. ábra b). Az Ordas-kő feltárásának meredek felsô szakaszán a folyamatosan cementált rétegek (homokkô padok) uralkodó jellege a meghatározó (6. ábra c), de helyenként a rétegmenti konkréciók is megfigyelhetôk. A folyamatosan cementált rétegek esetében jól kivehetô, hogy azok a korábbi izolált konkréciók továbbnövekedése és részleges vagy teljes összeolvadása révén alakultak ki.

Az Ordas-kövön és a Kis-kövön tanulmányozott, részlegesen kipreparálódott konkréciók határa nem éles a befoglaló kőzet felé, hanem diffúz határral, fokozatosan megy át abba. Ennek megfelelően - különösen az ellipszoidális, illetve a rétegszerúen elhelyezkedő, összeolvadó konkrécióknál — a mintázás során nem lehetett teljes konkréciókat gyújteni. A konkréciók és a szerkezeti elemek kapcsolata
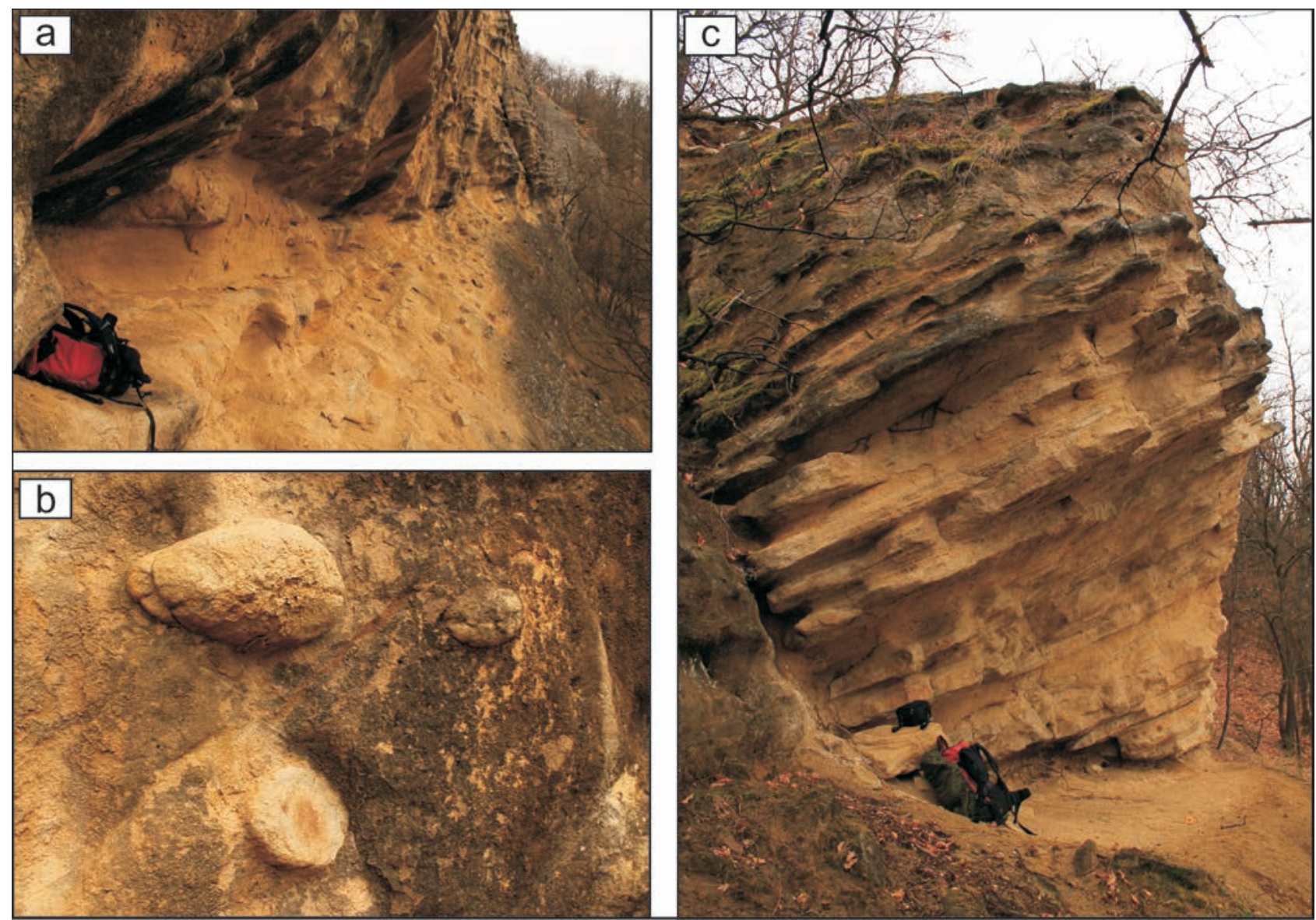

6. ábra. A Tarnalelesztől ÉNy-ra található Ordas-kő homokkő feltárásai

a) Az Ordas-kő monumentális feltárásának távlati képe, döntően rétegmenti konkréciókkal; b) Izolált, különféle méretű konkréciók az Ordas-kő alsó szakaszából. Az alsó konkréció metszetén Liesegang-gyürủk láthatók; c) Folyamatosan cementált rétegek az Ordas-kő feltárásában

Figure 6. Natural outcrops of the Ordas-kö, near Tarnalelesz

a) Monumental natural outcrop of the Ordas-kö with stratabound concretions; b) Isolated carbonate concretions of different size in the lower part of the Ordas-kö. Note: Liesegang rings also appear in the cross section of the lower concretion; c) Continuously cemented layers in the Ordas-kö outcrop 
szempontjából meg kell jegyeznünk, hogy a vizsgált feltárások közül az Ordas-kő alsó szakaszán tanulmányozhatók a legjobban az ún. deformációs szalagok (BEKE \& FODOR 2014). Megfigyeléseink alapján ezek nincsenek térbeli kapcsolatban a konkréciókkal (nem vetik el, nem kerülik ki azokat) az adott területen.

Bárna községtől É-ra található a Szer-kő Pétervásárai Homokkőből álló sziklaorma. A Szer-kövön feltárt, gyakran szerkezetmentes, finom-aprószemcsés homokkőben a cementációs típusok legtöbb formája jól megfigyelhetô: különféle vastagságú, folyamatosan cementált rétegek, rétegmenti és izolált konkréciók változatos alaki (pl. szferoidális, ellipszoidális) és méreti sokféleségben fordulnak elő (1. ábra b). A Szer-kő Bárna község felé néző oldalában több ellipszoidális konkréció összenövéséból kipreparálódott bizarr, gombaszerú sziklaalakzatok tanulmányozhatók (1. ábra c). A Szer-kövön begyưjtött konkréciók határa szintén nem éles, hanem diffúz a befoglaló kőzetek felé.

\section{Petrográfiai megfigyelések}

A Leleszi-völgy térségéből és a Szer-kőról begyújtött, szórtan darakavicsos, finom-durvaszemcsés homokkő mintákból készített vékonycsiszolatok mikroszkópi vizsgálata alapján egyértelmúen megállapítható, hogy azokban a vázalkotó szemcséket ásványtöredékek, kőzettörmelékek és bioklaszt vázelemek töredékei egyaránt alkotják. A szemcsék közepesen-jól koptatottak, illetve szögletesek, töröttek; osztályozottságuk közepes, az átlagos szemcseméret csökkenésével növekszik. A mátrix mennyisége elhanyagolható, a mintákat pátos kalcit cementálja. Az alábbi leírásban a konkréciók kialakulásával összefüggésbe hozható szempontokra térünk ki (pl. karbonátforrás, karbonátcement kompakcióhoz való viszonya, porozitás és oldódási folyamatok), a lehordási terület kőzettani összetételének, illetve a képződmény komplex diagenezis-történetének feltárása nem volt célunk.

A lelőhelytől és a szemcsemérettől függetlenül a homokkőben a leggyakoribb törmelékes eredetú vázalkotó ásványszemcse a kvarc $(\mathrm{Q})$, amelynek monokristályos $(\mathrm{Qm})$ és polikristályos $(\mathrm{Qp})$ változatai egyaránt előfordulnak (7. ábra), de a monokristályos a gyakoribb. A nagyobb méretú (dara) kvarcszemcsék - legalább részben — jól-kitûnően koptatottak, és nagy szfericitással rendelkeznek, azonban gyakran repedezettek, illetve töröttek; a repedésekben kalcit jelenik meg. Szintén gyakori törmelékes ásványszemcsék a különféle földpátok (F), amelyek töredezett, félig sajátalakú, illetve koptatott, változó mértékben átalakult szemcsék formájában jelennek meg. Jellegzetes komponens a sárgásbarna-élénkzöld glaukonit (glt), mely koptatottnak tűnő, kerekded-ovális alakú, illetve szabálytalan, préselt és/vagy repedezett, töredezett szemcsék formájában egyaránt megfigyelhető (7-9. ábra). A csillámok közül üde, nem deformált muszkovit és változó mértékben átalakult, kloritosodó-glaukonitosodó biotit ismerhetô fel.

A vizsgált mintákban gyakoriak az átalakult (kloritoso- dó-glaukonitosodó) magmás (pl. opak ásványokból, kloritból és plagioklászlécekből álló, bázisos vulkanit alapanyag), az üledékes (pl. radiolarit) és a metamorf eredetú (pl. grafitos agyag-aleurolitpala/fillit?) kőzettörmelék-szemcsék ( $\mathrm{R})$ is (7. ábra). A magmás és metamorf eredetú kőzettörmelék-szemcsék aránya a Kis-kőról származó mintákban a legnagyobb. Az üledékes kőzettörmelék-szemcsék között alárendelt mennyiségben koptatott dolomittörmelék azonosítható; mennyisége a Szer-kövön begyújtött konkréciókban a legnagyobb (10. ábra).

A karbonátos anyagú (kalcit) törmelékszemcsék közül ki kell emelnünk a különféle méretú és alakú bioklasztokat (bio; pl. héjtöredékek, bentosz foraminiferák), amelyek változó arányban az összes vizsgált csiszolatban megjelennek (pl. 7. ábra a, 8. ábra). A különböző helyről származó homokkő mintákban összefüggés figyelhetô meg a szemcseméret és a bioklaszttartalom között: a durvább szemcseméretû konkréciókból készült vékonycsiszolatokban (Kiskő, Ordas-kő) jelentôsebb a bioklaszttartalom, mint a finomabb szemcseméretű mintákban (Szer-kő). A bioklaszt eredetû́ kalcit becsült mennyisége átlagosan 10-20\%, de egyes mintákban (pl. Kis-kô) lokálisan akár 30-40\% is lehet. A durvaszemcsés homokkőben megfigyelhető nagyobb héjtöredékek jellegzetes, üreges belső szerkezetet mutatnak, illetve hullámos metszetú bordákkal díszítettek. A váztöredékek belsô ovális üregeit részben kalcitcement, részben glaukonit tölti ki. Ez utóbbi méretét, illetve megjelenését tekintve nagyon hasonló az önálló szemcseként előforduló, koptatottnak tûnố glaukonithoz. A Kis-kőrôl származó minták olyan foraminiferamaradványokat tartalmaznak, amelyek belsejében szintén gyakori a glaukonit. A KK2 mintában rotaloid, mészvázú bentosz foraminifera, Heterolepa $s p$. - valószínúleg $H$. dutemplei (D’ORB.) - fordult elő (SzUROMINÉ KORECZ A. szóbeli közlése, 2017).

Fontos néhány szót ejtenünk a homokkőben előforduló, különféle eredetû́ szemcsék érintkezésérôl is. A ridegen viselkedő kvarcszemcsék egymással pontszerúen vagy vonal mentén (lineárisan) érintkeznek (7. ábra $a, b ; 9$. és 10. ábra). A kvarc és az egyéb rideg szemcsék (pl. kőzettörmelék) nyomásoldódási felületek mentén történő benyomódása a könnyen oldódó szemcsékbe viszont már gyakran megfigyelhetô jelenség, jellegzetes konvex-konkáv, esetleg szutúrás határfelületeket (ez utóbbi jóval ritkább) kialakítva. Ez a szövet a rideg szemcsék és a bioklaszt héjtöredékek érintkezésekor a legszembetûnőbb (8. ábra $a-e$ ). A glaukonit plasztikus (préselt szemcsék; 7. ábra $a, 8$. ábra b), továbbá töréses deformációja (9. ábra a és $c$ ) egyaránt megfigyelhetô. A csillámok többnyire nem, vagy csak rugalmasan deformálódtak (íveltek, hajlítottak; 10. ábra), alárendelten kinkszerúen deformáltak. Az átalakult biotit a ridegebb szemcsék között ellapulva pszeudomátrixot alkot.

A vizsgált konkréciókban a homokkő egykori elsődleges szemcseközi pórusait pátos kalcit (a festést követôen rózsaszín) tölti ki, aminek becsült részaránya átlagosan 5$20 \%$. A pátos kalcitcement megjelenése többnyire mozaikos, változó kristálymérettel, de ritkán a héjtöredék felszínén rostos-prizmás cement reliktuma figyelhető meg a 

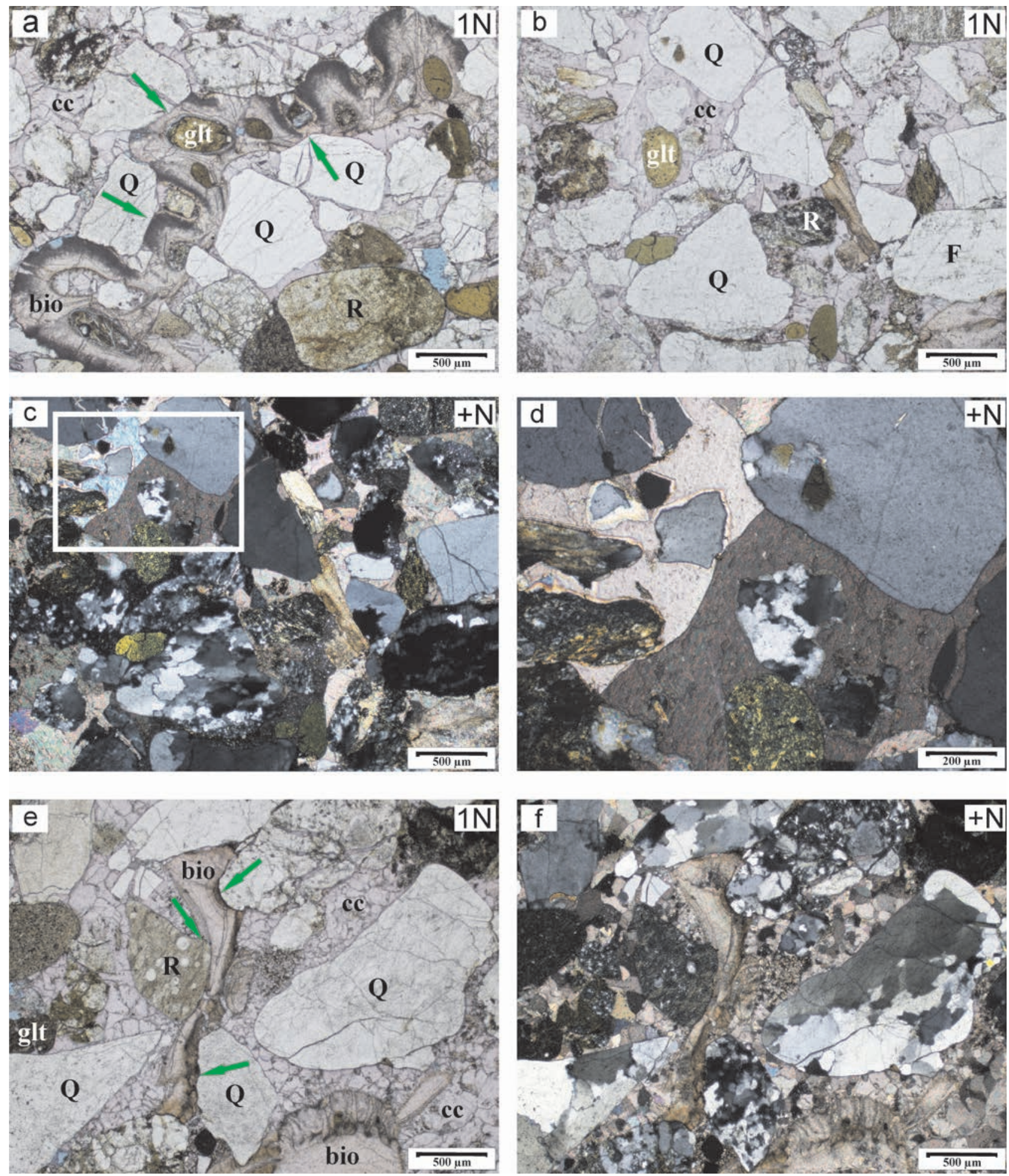

7. ábra. A Kis-kőről származó homokkő konkréció (KK1) ásványos összetétele és szöveti jellemzői (festett vékonycsiszolatok; a és b: belső rész, c-f: külső rész) a) Bioklaszt-vázelem és kvarc érintkezése nyomásoldódási felületek mentén, a vázelemüregekben glaukonittal; b) és c) Pont és vonal mentén érintkezỏ kvarcszemcsék, földpát, glaukonit és kőzettörmelék-szemcsék kalcitcementtel. A fehér kerettel jelölt rész a „d” jelủ képen látható; d) A szemcséket körülvevő poikilotópos kalcitcement; e) és f) Bioklaszt vázelem, kvarcés közettörmelék-szemcse (radiolarit) érintkezése nyomásoldódási felületek mentén

Jelmagyarázat: $\mathrm{Q}$ = kvarc, $\mathrm{F}$ = földpát, glt = glaukonit, $\mathrm{R}$ = közettörmelék-szemcse, bio = bioklaszt vázelem, cc = kalcitcement, zöld nyíl = nyomásoldódási felszín (kémiai kompakciós bélyeg)

Figure 7. Mineralogical and textural features of the sandstone sample KKI derived from the Kis-kö (stained thin sections; $1 N$ and $+N$ : parallel and crossed nicols, respectively; $a$ and $b$ : inner part of the concretion, $c-f$ : outer part of the concretion)

a) Pressure solution contacts between a bioclast fragment and quartz grains. Note: intragranular pores of the bioclast are filled with glauconite; b) and c) Point to linear contacts between quartz, feldspar, glauconite and rock fragments, intergranular pores are filled by calcite cement. Area marked by a white rectangle is shown in Figure 6d; d) Poikilotopic calcite cement around the grains; e) and f) Bioclast, quartz and rock fragment (radiolarite) contacts along pressure solution surfaces

Abbreviations: $Q=$ quartz, $F=$ feldspar, glt $=$ glauconite, $R=$ rock fragment, bio $=$ bioclast, $c c=$ calcite cement, green arrow = pressure solution surface (chemical compaction feature) 

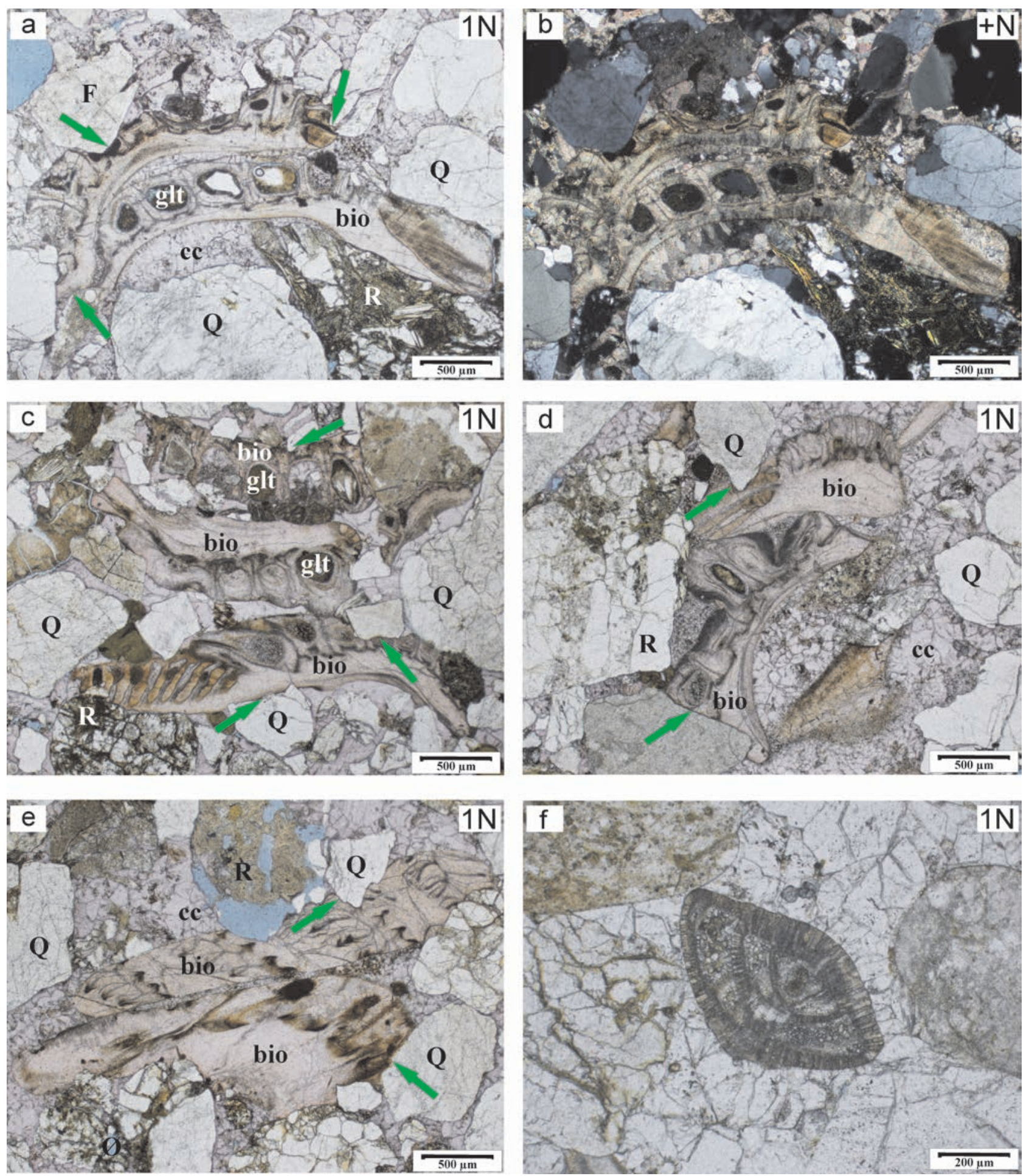

8. ábra. A Kis-kőről származó homokkő konkréciók ásványos összetétele és szöveti jellemzői (a-e: festett vékonycsiszolatok)

a) és b) Bioklaszt héjtöredék nyomásoldódási bélyegekkel. A vázelem belső pórusait glaukonit, illetve törmelékes kvarc tölti ki (KK1 minta, belső rész). A héjtöredék alsó részén rostos tengeri cementen kialakult prizmás kalcitcement-továbbnövekedés figyelhető meg; c) Bioklaszt töredékben gazdag homokkő (KK1 minta, belső rész); d) Bioklaszt hétöredékek kémia kompakciós bélyegekkel, kalcit mozaikpáttal cementált homokkőben (KK1 minta, külső rész); e) Kalcitcement utáni másodlagos pórus bioklasztdús homokkőben (KK2 minta, belsô rész); f) Mészvázú rotaloid foraminifera (Heterolepa sp.), KK2 minta, belső rész

Jelmagyarázat: $\mathrm{Q}=$ kvarc, glt = glaukonit, $\mathrm{R}=$ kőzettörmelék-szemcse, bio = bioklaszt vázelem, $\mathrm{cc}=$ kalcitcement, zöld nyil = nyomásoldódási felszín

Figure 8. Mineralogical and textural features of the sandstone samples derived from the Kis-kö (a-e: stained thin sections; $1 N$ and $+N$ : parallel and crossed nicols, respectively)

a) and b) Large bioclast fragment with pressure solution features. Its intragranular pores are filled with glauconite and detrital quartz (in the middle), sample KK1 (inner part of the concretion) Note: at the lower margin of the bioclast calcite crystals of prismatic spar overgrowing fibrous marine cement occur; c) Bioclast fragment-rich sandstone sample (sample KKI, inner part of the concretion); d) Bioclast fragments showing chemical compaction features in the KKI sandstone sample cemented by calcite mosaic spar (outer part of the concretion); e) Secondary intragranula porosity within a rock fragment predated by calcite cement in the bioclast-rich sandstone sample (sample KK2, inner part of the concretion); f) Calcareous rotaloid foraminifera (Heterolepa sp.), sample KK2 (inner part of the concretion)

Abbreviations: $Q=$ quartz, $g l t=$ glauconite, $R=$ rock fragment, bio $=$ bioclast, $c c=$ calcite cement, , reen arrow = pressure solution surface 

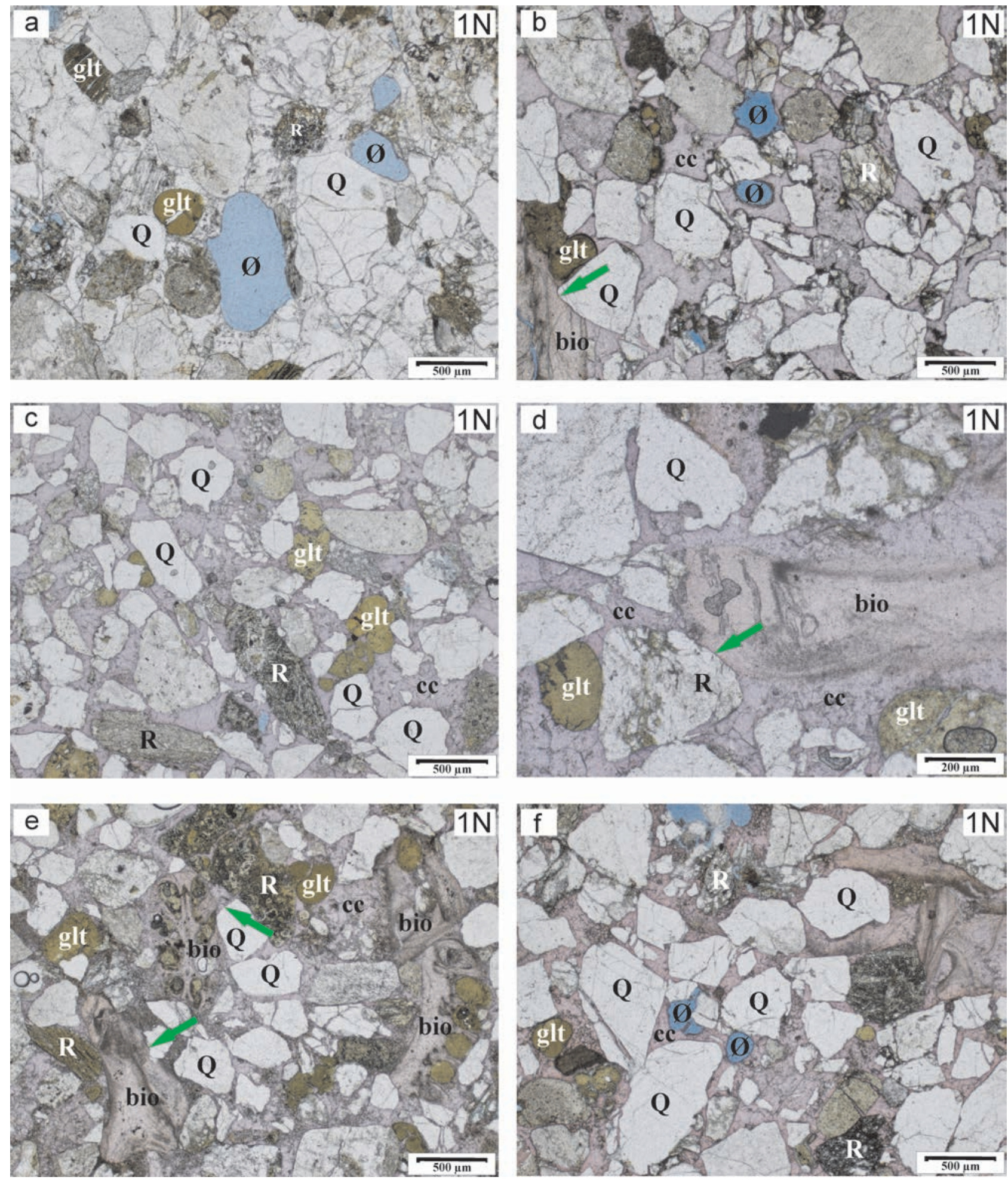

9. ábra. A Kis-kőről és az Ordas-kőről származó konkréciók ásványos összetétele és szöveti jellemzői (b-f: festett vékonycsiszolatok)

a) Kvarc-, glaukonit-és kőzettörmelék-szemcsék kalcitcementtel, továbbá másodlagos szemcseoldódási pórusokkal (KK2 minta, belsỏ rész); b) Másodlagos pórusok, továbbá a felszíni mállás miatt limonitos filmréteggel boritott szemcsék (KK2 minta, külső rész); c-e) Kalcittal cementált, bioklaszt vázelemeket és glaukonitot tartalmazó konkréció az Ordas-kőről (OK3 minta, belsỏ rész). A szemcsék általában lazán érintkeznek, viszont a glaukonit töréses deformációja megfigyelhető; f) Másodlagos pórusok az Ordas-kỏi minta külső részéböl (OK3 minta)

Jelmagyarázat: $\mathrm{Q}$ = kvarc, glt = glaukonit, $\mathrm{R}$ = kőzettörmelék-szemcse, bio = bioklaszt vázelem, $\mathrm{cc}$ = kalcitcement, $\varnothing$ = pórus, zöld nyil = nyomásoldódási felszín

Figure 9. Mineralogical and textural features of the sandstone samples derived from the Kis-kö and Ordas-kö (b-f: stained thin sections; 1N: parallel nicols)

a) Quartz, glauconite and rock fragments as grains together with secondary pores after grains (sample KK2, inner part of the concretion). Note: intergranular pores are generally filled by calcite cement; $b$ ) Secondary pores and grains with limonite coating (sample KK2, outer part of the concretion); $(-e)$ Bioclast-and glauconite-bearing concretion cemented by calcite from the Ordas-ko (sample OK3, inner part of the concretion). Relatively loose packing of grains and brittle deformation of glauconite is also visible; f) Secondary pores in the outer part of the concretion from the Ordas-kö (sample OK3)

Abbreviations: $Q=$ quartz, glt $=$ glauconite, $R=$ rock fragment, bio $=$ bioclast, $c c=$ calcite cement,$\varnothing=$ pore, green arrow $=$ pressure solution surface 

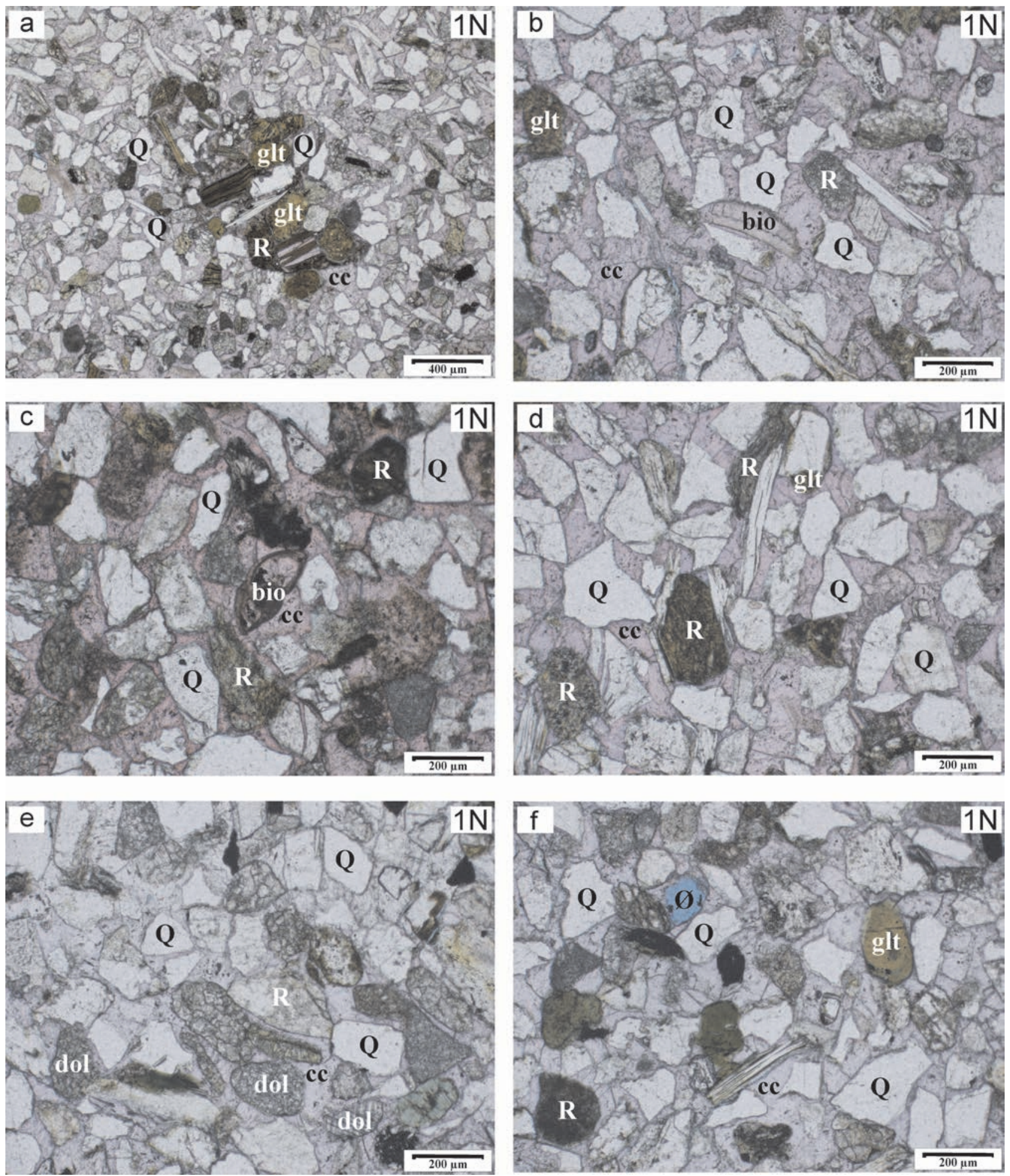

10. ábra. A Szer-kőről származó konkréció (SZK1 minta) ásványos összetétele és szöveti jellemzői (festett vékonycsiszolatok) a konkréció közepétől (a) kifelé (f) haladva

a-d) Pont és vonal mentén érintkező kvarc-, glaukonit-, bioklaszt-és kőzettörmelék-szemcsék kalcitcementtel. A laza szemcseilleszkedés, illetve a csillámlemezek deformációjának teljes hiánya korai cementációra utal; c) Mészvázú foraminifera (középen); e) Közepesen-jól koptatott törmelékes dolomitszemcsék; f) Másodlagos szemcseoldódás pórus a konkréció külsô részén

Jelmagyarázat: $\mathrm{Q}$ = kvarc, glt = glaukonit, $\mathrm{R}$ = kỏzettörmelék-szemcse, dol = dolomit, bio = bioklaszt vázelem, cc = kalcitcement, $\varnothing$ = pórus, zöld nyil = nyomásoldódási felszín

Figure 10. Mineralogical and textural features of the SZK1 sandstone samples derived from the Szer-kö (stained thin sections, $1 N$ : parallel nicols; thin sections of the concretion from the center to the margin)

a-d) Point to linear contacts between quartz, glauconite, bioclast and rock fragments, respectively. Intergranular pores are filled by calcite cement. Relatively loose packing of grains and the undeformed nature of mica flakes clearly suggest an early cementation event; c) Calcareous foraminifera (in the middle); e) Moderately to well rounded dolomite fragments as detrital grains; f) Secondary pore in the outer part of the concretion

Abbreviations: $Q=$ quartz, glt $=$ glauconite, $R=$ rock fragment, dol $=$ dolomite, bio $=$ bioclast, $c c=$ calcite cement,$\varnothing=$ pore, green arrow $=$ pressure solution surface 
konkréció központi részén ( 8 . ábra $a$ és $b$ ); a külső régióban pedig helyenként poikilotópos kalcitcement figyelhető meg (7. ábra b-d). Számos esetben mikropátos-pszeudopátos kalcit található a bioklaszt vázelemek belsejében (8. ábra c és $f$ ). A kalcit a cementen kívül földpátban, kőzettörmelékben és kvarcban helyettesítés formájában is megjelenhet (9. ábra $c$ és $d$ ). A makroszkóposan Liesegang-gyuurúket tartalmazó mintákban a szemcsehatárokon vékony limonitos film figyelhetố meg (9. ábra $b$ ).

A csiszolatokban kitöltetlen elsődleges makropórusok nem láthatók, azonban helyenként többnyire kerekded metszetú, másodlagos, szemcseoldódási pórusok alakultak ki (pl. 9. ábra $a$ és $b$ ), amelyek a vizsgált konkréciók külsô részén gyakoribbak.

\section{Diszkusszió}

A Pétervásárai Homokkő Formációban a konkréciók genetikája, valamint a homokkő karbonátos cementációjának részletei napjainkban sem ismertek kellô részletességgel. A közelmúltban SzŐCs et al. (2015) végeztek részletes kutatást egy kishartyáni mintaterületen, eredményeik alapján azonban nem dönthetô el egyértelmúen, hogy a karbonátos cementációt okozó oldatok külsô vagy belső forrásból származtak-e.

A Kis-kő, az Ordas-kő és a Szer-kő környezetében végzett terepi megfigyeléseink alapján a konkréciókhoz kapcsolódva nem figyeltünk meg vetôket a kôzettestben. A feltárásoknál viszont gyakran találkoztunk a makroszkóposan is könnyen felismerhetố ún. deformációs szalagokkal (BEKE \& FODOR 2014), amelyek azonban nem mutattak összefüggést a konkréciókkal, így nem utaltak közvetlenül külsô karbonátforrásra. A deformációs szerkezetektől független, rétegszerúen elhelyezkedő, izolált konkréciósorok arra engednek következtetni, hogy a vizsgált területen a homokkő üledékképződési folyamatai - a szemcseméret eloszlásán és a rétegzettségen keresztül - szoros kapcsolatban álltak a képződmény karbonátos cementációjával, ami felveti a belsô karbonátforrás lehetőségét.

A sekélytengeri üledékes kőzetekben a karbonátcement többféle belső forrásból származhat. Ezek közül a legjelentősebb az ilyen típusú üledékben nagy mennyiségben jelen lévő fosszíliák (pl. csigák, kagylók) vázelemeinek kalciumkarbonát (aragonit/kalcit) anyaga (BJøRKUM \& WALDERHAUG 1990, WALDERHAUG \& BJøRKUM 1998, MARShALL \& PIRRIE 2013). A Pétervásárai Homokkő rétegsorát korábban leíró szakemberek (pl. BÁLDI 1983, 1986; FôZZY \& LEÉL ỐSSY 1985; HÁMOR 1985) az alsó tagozatait makroszkóposan gyakorlatilag faunamentesnek találták, míg a felsőbb részekben helyenként lumasellaszerú betelepüléseket határoztak meg. Az Ilonavölgyi Tagozat gazdag normál sós vízi, meleg sekélytengeri faunájában aragonithéjú és kalcitházú fajok egyaránt jellemzôk (BÁLDI 1983). FôZY \& LEÉL ŐsSY (1985) szerint a Darnó-zónát átlépve az azonos kort és üledékképződési környezetet képviselő Darnói Konglomerátum már csak szegényes és rosszabb megtartású faunát tartalmazott.
Aragonithéjú faunaelemet egyáltalán nem találtak, amit munkájukban diagenetikus oldás következményeként értelmeztek. SzTANó \& JózSA (1996) alapján a két képződmény törmelékének anyaga (ofiolit eredetú kőzettörmelék-szemcsék, intermedier magmás, metamorf és üledékes eredetú kőzettörmelék-szemcsék) részben eltérő forrásterületről származik, továbbá lényegesen eltérő üledékképződési környezetben keletkezett, bár faunaegyüttesük azonos.

A belső karbonátforrás bioklasztok oldódásából származó magyarázatát a vizsgált minták mikroszkópos vizsgálata egyértelmúen alátámasztotta, ami alapvetô jelentôségú a konkrécióképződés genetikájának megítélése szempontjából az adott területen. A csiszolatok döntő többségében a kőzetalkotó szilikátos szemcséknél nagyobb méretú, kalciumkarbonát anyagú bioklaszt vázelemek találhatók, amelyek a legtöbb helyen kémiai kompakciós bélyegeket mutatnak ( 8 . ábra $a-e$ ). Feltételezzük, hogy a meleg, sekélytengeri faunát képviselő bioklasztok metastabil aragonit ( \pm nagy $\mathrm{Mg}$ tartalmú kalcit) anyagának oldódása közvetlenül a betemetődést követôen, a szuboxikus-anoxikus zónában lezajlott. Ezt követően a stabilabb, de sziliciklasztos rendszerben viszonylag könnyen oldódó kalcit vázelemek részleges (vagy kisebb méret esetén teljes) oldódása kezdődött meg, ami a rideg szemcsék (pl. kvarc) nyomásának hatására következett be. A vázelemek anyagának átrendeződése így — valószínúleg több egymást követő fázisban — aktívan részt vett a kalcittal cementált konkréciók létrehozásában. Kisebb arányban, de a magmás, illetve metamorf kőzettörmelék-szemcsék plagioklásztartalma (pl. SzTANó \& JózSA 1996, SzŐCS et al. 2015) szintén figyelembe vehetô, mint $\mathrm{Ca}^{2+}$-forrás az adott rendszerben.

Belső eredetú karbonátforrásnál az átrendeződő ionoknak csak kisebb távolságot kell megtennie; amihez a hatékony anyagáramlást — a lokálisan változó koncentrációkülönbség miatt - a diffúzió szabályozza (BJøRKUM \& WALDERHAUG 1990). Ezt a tanulmányunkban bemutatott konkréciók nem éles, hanem diffúz határa szintén alátámasztja. A porózus és a cementgazdag homokkő közötti fokozatos átmenetet fúrt minta segítségével Szőcs et al. (2015) is dokumentálták. A szferoidális, ellipszoidális megjelenés tehát a felszíni részleges (illetve lokálisan teljes) kipreparálódás eredménye, azaz a tanulmányozható konkréciók maximális mérete az eredetileg cementált térfogat minimális értékét közelíti.

A fentiek alapján véleményünk szerint a napjainkban megfigyelhető gyér ősmaradvány-tartalom nem jelenti azt, hogy eredetileg is faunaszegény volt a homokkő összlet, hanem az üledékszállítás során felőrlődött, áthalmozott töredékek utólagos, diagenetikus folyamatok során részben (pl. kalcit anyagú vázelemek), illetve teljesen (pl. aragonit anyagú vázelemek) feloldódtak. A cementált egységek, konkréciók izolált, meg-megszakadó vagy folyamatos megjelenését valószínúleg a nukleuszok (pl. bioklaszt vázelemek, karbonátos kőzettörmelékek) üledéken belüli homogén vagy heterogén eloszlása mellett a homokkő szemcseösszetétele, osztályozottsága és rétegzettsége is jelentősen befolyásolta (pl. BJøRKUM \& WALDERHAUG 1990). A jól osztályozott, fi- 
nomszemcsés, ezáltal közel homogén, izotróp tulajdonságú üledékekben a szferoidális jellegú konkréciók dominálnak (pl. Szer-kő), míg a rétegzett, rétegszilikátokat, illetve megnyúlt héjtöredékeket is tartalmazó, ezáltal anizotróp üledékekben (pl. Kis-kő) az ellipszoidális konkréciók megjelenése a gyakoribb (1. táblázat). Ezeket az egy kőzettesten belül is jelentősen eltérô cementációs különbségeket hangsúlyozták ki azok a felszíni / felszín közeli mállási folyamatok, amelyek a Pétervásárai Homokkövet érték a kiemelkedés következtében (SzŐ́cs et al. 2015).

Korábban már utaltunk rá, hogy részleteiben nem tisztázott, hogy a Pétervásárai Homokkőben jelen lévő kalcitcement a diagenezis mely tartományában válhatott ki. SzŐ́cs et al. (2015) a mezo- vagy telogenezis tartományába teszi a konkréciókkal összefüggésbe hozható karbonátos cement megjelenését a kishartyáni feltárásban. A Kis-kőről, az Ordas-kőről és a Szer-kőről származó mintákból készült vékonycsiszolatok mikroszkópos elemzése alapján véleményünk szerint a konkréciókat kialakító kalcitcement kiválása már a mechanikai kompakció korai fázisában (tengeri eogenezis) megkezdődött a mintaterületünkön. Ezt jelzik a homokkövet alkotó, ridegen viselkedô és lazán érintkezó (pontszerû és vonalmenti érintkezések) ásvány- és kőzetszemcsék (7. ábra b), amelyek a mechanikai kompakció korai fázisát tükröző szövetet rögzítettek a cementációs folyamat során. Erre utal továbbá a rostos-prizmás kalcitcement reliktuma az általunk vizsgált egyik konkréció központi részén (8. ábra $a$ és $b$ ). A változó kristályméretú mozaikos kalcitpát, illetve a konkréció külsô régiójában kialakult poikilotópos kalcitcement (7. ábra $b-d$ ) alapján úgy gondoljuk, hogy a kalcitos cementáció a betemetôdés során válhatott intenzívvé, így a mezogenezis tartományára is kiterjedhet. Telogenetikus kalcitcementre utaló petrográfiai bélyegeket ugyanakkor nem figyeltünk meg. A diagenezistörténet pontosításához a durvább szemcseméretú konkréciók (pl. Kis-kő) eltérô petrográfiai megjelenésú cementgenerációinak részletes vizsgálata (pl. katódlumineszcens mikroszkópia, szövetszelektív geokémiai vizsgálat) hasznos információkat szolgáltathat a jövőben.

Külön említést kell tennünk a homokkőben helyenként jelentős mennyiségben feldúsuló glaukonitról is. Eredetükkel korábban több szerző foglalkozott (pl. BÁLDI 1983, HÁMOR 1985, FEKETE 2003, SzŐCs et al. 2015), akik allotigén és autigén képződésüket egyaránt elképzelhetônek tartották. BÁLDI (1983) a lencsés megjelenés, az osztályozódási viszonyok, illetve publikálatlan radiometrikus koradatok alapján egyértelmúen az áthalmozott eredet mellett foglalt állást. FEKETE (2003) ugyanakkor a Pétervásárai Homokkőból szeparált glaukonitszemcsék lapos-ovális alakját az erősen mozgatott üledékfelszínen való ide-oda mozgatottsággal magyarázta, amit bizonyítékként tekintett a glaukonit autochton (paraautochton) keletkezésére.

Mikroszkópos megfigyeléseink alapján a jól koptatott megjelenésú (kerekded vagy ovális metszetư) szemcsék és a karbonátos fosszíliák vázüregeiben megfigyelhető glaukonit között kapcsolat valószínúsíthető (7. ábra $a$ és $b$ ). Véleményünk szerint a glaukonitszemcsék — legalább rész- ben — az egykori sekélytengeri fauna elpusztulása után azok vázelemüregeiben kristályosodtak ki, azokkal együtt halmozódtak át az alsó-miocén üledékgyújtő távolabbi részeibe. A koptatott jelleg tehát nem a szállítás eredményeként alakult ki, hanem a fosszíliák vázelemüregeiben lévő egykori szabad pórusok alakját és méretét őrizték meg, majd a vázelemek szállítás közbeni összetörésének hatására azokból részben kiperegtek. A felvázolt allochton eredetet bizonyítja a glaukonitszemcsék egy részének rideg töréses viselkedése a vizsgált vékonycsiszolatokban (7. ábra b). Az „éretlen” glaukonitszemcsékre a plasztikus deformáció megjelenése jellemző (pl. BoGGs 2009), amit a vázelemek üregeiből mint elszigetelt, védett környezetből az áthalmozás során kipergő szemcsék megjelenése tükröz. Megjegyzendő továbbá, hogy a glaukonitképződés lassú folyamat, ami reduktív környezetben megy végbe a tengeraljzaton, kizárólag kis üledékfelhalmozódási ráta mellett (pl. SCHOlle \& Ulmer Scholle 2003). Figyelembe véve, hogy a Pétervásárai Homokkő üledékképződési rendszere kezdetben aggradációs, majd progradációs volt (SzTANó \& TARI 1993, SzTANÓ 1994, SZTANÓ \& JÓzSA 1996), valószínútlen, hogy hosszú távon biztosítottak voltak a glaukonitképződés környezeti feltételei, ami szintén az áthalmozott eredetet erősíti.

Mind a glaukonit, mind az azt hordozó ősmaradványok egyik potenciális forrása az Egri Formáció lehetett (vö. Heterolepa sp., Szurominé KoreCz szóbeli közlése, 2017), mely a térségben több helyen — jelen orientáció szerint a Pétervásárai Homokkő vizsgált feltárásaitól délre — a felszínen is tanulmányozható (HoRvÁTH 1983, FEKETE 2003). Ezt a feltételezést támasztja alá FEKETE (2003) megfigyelése, aki az egri mintákból elkülönített bipiramisos kvarcokhoz hasonló — azonban kissé koptatott — idiomorf kvarckristályokat azonosított a Pétervásárai Homokkövet képviselő kőzetmintákban.

\section{Konklúzió}

Az alsó-miocén Pétervásárai Homokkő Formáció sekélytengeri képződményei az elterjedési területein látványos formakincset alkotva bukkannak a felszínre. A mállási folyamatok hatására az erősebben cementált részek izolált, illetve rétegmenti konkréciók, valamint folyamatosan cementált rétegek formájában preparálódtak ki a kevésbé cementált egységek környezetéből. A Leleszi-völgy térségéből vizsgált konkréciókban a homokkő egykori elsődleges szemcseközi pórusait pátos kalcit tölti ki, amelynek becsült részaránya átlagosan 5-20\%. A kalcitcement eredetének meghatározása szempontjából lényeges, hogy valamennyi mintában azonosítottunk bioklaszt vázelemeket, amelyek a durvább szemcseméretû́ üledékes egységekben (Kis-kő, Ordas-kő) sokkal gyakoribbak, mint a finomabb szemcseméretúekben (Szer-kő). Eredményeink alapján tehát a kalcitból álló cement legalább részben belsô eredetû a vizsgált területen. Annak egyik elsődleges forrása a törmelékes üledékbe a lerakódásakor beágyazódó meszes héjú fosszíliák 
kémiailag instabil, aragonitból álló váza lehetett, mely már a diagenezis korai fázisában (tengeri eogenezis) feloldódott, anyaga átrendeződött. A betemetődéssel erősödő kompakciós folyamatok hatására a kalcithéjak is oldódni kezdtek. Az üledékben található nukleációs pontok (pl. karbonátos vázelemek, karbonátos kőzettörmelék) körül a rendelkezésre álló ionok mennyisége és a diffúziós koncentráció-gradiensnek megfelelően mehetett végbe a kalcitcement kiválása, illetve a konkrécióképződés. A diffúzió vezérelte folyamat a karbonátforrás leürüléséig és/vagy egy másik konkréció hatásterületének eléréséig tartott.

Megfigyeléseink szerint a Pétervásárai Homokkőben található glaukonitszemcsék nagy valószínúséggel áthalmozott eredetűek. A glaukonit jelentős része a karbonátos anyagú élőlények ovális metszetú vázelemüregeiben képződött, amit az áthalmozódás során széttört héjakból kipergett szemcsék koptatottnak túnő alakja tükröz. FeKETE (2003) ásványtani eredményeivel összhangban úgy gondoljuk, hogy a vizsgált területen a Pétervásárai Homokkő Formáció egyik lehetséges törmelékforrása az Egri Formáció volt, mely a Mátra és a Bükk előterében nagyobb területeken, a felszínen ma is megtalálható.

\section{Köszönetnyilvánítás}

Köszönettel tartozunk BENCSIK Attilának (SZTE TTIK Ásványtani, Geokémiai és Kőzettani Tanszék) a vékonycsiszolatok elkészítésében, valamint SzUROMINÉ KORECZ Andreának (MOL Nyrt.) a mikrofosszíliák meghatározásában nyújtott segítségéért. Az SZTE Ásványtani, Geokémiai és Kőzettani Tanszékén a homokkő petrográfiai munkát az Emberi Erőforrások Minisztériuma UNKP-18-4-SZTE-16 kódszámú és az Innovációs és Technológiai Minisztérium ÚNKP-19-4-SZTE-34 kódszámú Új Nemzeti Kiválóság Programja támogatja.

\section{Irodalom — References}

AJTAY F. 1994: A feleki gömbkövek (konkréciók) elterjedése, sztratigráfiai helyzete és keletkezésük ôsföldrajzi feltételei. — Múzeumi Füzetek, Erdélyi Múzeum-Egyesület, Kolozsvár, 120-127.

ApPelo, C. A. J. \& PostMA, D. 2009: Geochemistry, groundwater and pollution. — 2nd edition, CRC Press, Fourth corrected reprint, 649 p. https://doi.org/10.1201/9781439833544

Bajnóczi, B., Horváth, Z., Demény, A. \& Mindszenty, A. 2006: Stable isotope geochemistry of calcrete nodules and septarian concretions in a Quaternary 'red clay' paleovertisol from Hungary. — Isotopes in Environmental and Health Studies 42, 335-350. https://doi.org/10.1080/10256010600991045

BALOGH K. 1991: Szedimentológia II. — Akadémiai Kiadó, Budapest, 57 p.

BARTA, G. 2011: Secondary carbonates in loess-paleosoil sequences: a general review. — Central European Journal of Geosciences 3/2, 129-146. https://doi.org/10.2478/s13533-011-0013-7

BathuRst, R. G. C. 1975: Carbonate Sediments and their Diagenesis. — Elsevier, Amsterdam, 2nd ed., 658 p.

BÁLDI T. 1983: Magyarországi oligocén és alsómiocén formációk. — Akadémiai Kiadó, Budapest, 292 p.

BÁLDI, T. 1986: Mid-Tertiary stratigraphy and palaeogeographic evolution of Hungary. — Akadémiai Kiadó, Budapest, 250 p.

BEKE B. \& FodoR L. 2014: Deformációs szalagok porózus, szemcsés kőzetekben. — Földtani Közlöny 144/1, 255-274.

BEKE, B. \& FodoR, L. 2015: Separating Cenozoic deformation events in NE-Hungary based on combination of deformation band evolution and fault slip data. - Tectonic Studies Group Annual Meeting: Programme \& Abstract Volume 22.

Berner, R. A. 1980: Early Diagenesis - a Theoretical Approach. — Princeton University Press, Princeton, NJ.

BJøRKUM, P. A. \& WALDERHAUG, O. 1990: Geometrical arrangement of calcite cementation within shallow marine sandstones. — EarthScience Reviews 29, 145-161. https://doi.org/10.1016/0012-8252(0)90033-r

Boggs, S. 2009: Petrology of Sedimentary Rocks. — Cambridge University Press, Cambridge, 600 p. https://doi.org/10.1017/ cbo9780511626487

DiCKsOn, J. 1966: Carbonate identification and genesis as revealed by staining. — Journal of Sedimentary Petrology 36, $491-505$. https://doi.org/10.1306/74d714f6-2b21-11d7-8648000102c1865d

FEKETE J. 2003: Felsó-oligocén és alsó-miocén glaukonitos képzódmények ásványtani vizsgálata. — Diplomamunka, ELTE Ásványtani Tanszék, Budapest, 128 p.

FôZY I. \& LEÉL ŐssY Sz. 1985: Két kelet-mátrai alsómiocén konglomerátum molluszka faunájának összehasonlító vizsgálata — Földtani Közlöny 115/1-2, 181-192.

Giles, M. R., Stevenson, S., Martin, S. V., Cannon, S. J. C., Hamilton, P. J., Marshall, J. D. \& Samways, G. M. 1992: The reservoir properties and diagenesis of the Brent Group: a regional perspective. - In: Morton, A. C., Haszeldine, R. S., Giles, M. R. \& BROwn, S. (eds): Geology of the Brent Group. Spec. Publ. Geol. Soc. Lond., 61, 289-327. https://doi.org/10.1144/gsl.sp.1992.061.01.16

HÁmor, G. 1985: Geology of the Nógrád-Cserhát area. — Geologica Hungarica series Geologica 22, 307 p.

HoRvÁtH G. 2007: Kőzetminőséghez kötött formák az Északi-középhegység egyes homokköves kistájain. — In: FrISNYÁK S. \& GÁL A. (szerk.): Dr. Peja Gyózó emlékkönyv: A Szerencsen 2007. november 16-án megtartott emlékkonferencia előadásai. Nyíregyháza, 57-78.

HoRváth M. 1983: Az egri és novaji típusszelvények foraminifera-faunája. — Földtani Közlöny 113/1, 57-79.

Horváth Z., Micheli E., MindsZenty A. \& Berényi Üveges J. 2002: Posztpannóniai környezetváltozásra utaló terepi és mikromorfológiai sajátosságok a visontai lignitösszlet fedőrétegsorában (Visonta, Észak-Magyarország). — Földtani Közlöny 132/küilönszám, 43-51. 
KISS J. \& GRossz Á. 1958: Konkrécióképződés és új karbonátos fácies a Mecsek-hegységi permi pszammitos összletben. — Földtani Közlöny 88/4, 416-427.

Konrád, Gy., Sebe, K., Halász, A. \& Babinszki, E. 2010: Sedimentology of a Permian playa lake: the Boda Claystone Formation, Hungary. — Geologos 16/1, 27-41. https://doi.org/10.2478/v10118-010-0002-1

Marshall, J. D. \& PIRRIE, D. 2013: Carbonate concretions - explained. — Geology Today 29/2, https://doi.org/ 10.1111/gto.12002

MoRAD, S. 1998: Carbonate cementation in sandstones: distribution patterns and geochemical evolution. - In: MoRAD, S. (ed.): Carbonate Cementation in Sandstones. - Special Publication Number 26 of the International Association of Sedimentologists, 126. https://doi.org/10.1002/9781444304893.ch1

Nagymarosy, A. \& BÁLdi-Beke, M. 1988: The position of the Paleogene formations of Hungary in the standard nannoplankton zonation. - Annales Univ. Sci. Eotvos, Sect., Geol. 28, 3-25.

SAIGAL, G. C. \& BJøRLIKKE, K. 1987: Carbonate cements in clastic reservoir rocks from offshore mid Norway — relationship between isotopic composition, textural development and burial depth. — In: MArshaLl, J. D. (ed.) Diagenesis of Sedimentary Sequences. Spec. Publ. Geol. Soc. Lond., 36, 313-324. https://doi.org/10.1144/gsl.sp.1987.036.01.22

Scholle, P. \& Ulmer Scholle, D. 2003: A Color Guide to the Petrography of Carbonate Rocks: Grains, textures, porosity, diagenesis. - American Association of Petroleum Geologist, Tulsa, $458 \mathrm{p}$.

SEILACHER, A. 2001: Concretion morphologies reflecting diagenetic and epigenetic pathways. - Sedimentary Geology 143, 41-57. https://doi.org/10.1016/s0037-0738(01)00092-6

Sellés-MARTínEZ, J. 1996: Concretion morphology, classification and genesis. — Earth-Science Reviews 41, 177-210. https://doi.org/ 10.1016/s0012-8252(96)00022-0

Sümegi, P., Gulyás, S., Persaits, G., PÁll, D. G. \& Molnár, D. 2011: The loess-paleosol sequence of Basaharc (Hungary) revisited: Mollusc based paleoecological results for the Middle and Upper Pleistocene. - Quaternary International 240, 191-192. https://doi.org/10.1016/j.quaint.2011.05.005

SzŐCs E., HIPS K., JózSA S. \& BENDő Zs. 2015: A kora-miocén Pétervásárai Homokkő diagenezis-története. — Földtani Közlöny 145/4, $351-366$.

SzTANó, O. 1994: The tide-influenced Pétervására Sandstone, early Miocene, northern Hungary: sedimentology, palaeogeography and basin development. — Geologica Ultraiectina 120, 155 p.

SZTANó, O. \& JózSA, S. 1996: Interaction of basin-margin faults and tidal currents on nearshore sedimentary architecture and composition: a case study from the Early Miocene of northern Hungary. — Tectonophysics 266, 319-341.

SZTANó, O. \& TARI, G. 1993: Early Miocene basin evolution in northern Hungary: tectonics and eustasy. — Tectonophysics 226, 485-502.

VARGA, A., RAucsiK, B. \& BAJNóczy, B. 2012: Nodular calcrete from the Lower Permian Korpád Sandstone Formation (borehole Dinnyeberki 9015, Mecsek Mts, Hungary) and its palaeoenvironmental significance. — Földtani Közlöny 142/4, 375-378.

VASS, D. \& ElEČKO, M. 1992: Vysvetlivky ku geologickej mape Lučenskej kotliny a Cerovej vrchoviny 1:50 000. — Geol. ústav D. Štúra, 7-196.

WAlderhaUG, O. \& BJøRKUM, P. A. 1998: Calcite cement in shallow marine sandstones: growth mechanisms and geometry. - Spec. Publs int. Ass. Sediment. 26, 179-192. https://doi.org/10.1002/9781444304893.ch8

WiLKInSON, M. \& DAMPIER, M. D. 1990: The rate of growth of sandstone-hosted calcite concretions. — Geochim. Cosmochim. Acta, 54, 3391-3399. https://doi.org/10.1016/0016-7037(90)90293-t

Yoshida, H., Ujihara, A., Minami, M., Asahara, Y., Katsuta, N., Yamamoto, K., Sirono, S., Maruyama, I., Nishimoto, S. \& MetCALFE, R. 2015: Early post-mortem formation of carbonate concretions around tusk-shells over week-month timescales. Nature Scientific Reports 5, https://doi.org/10.1038/srep14123

Kézirat beérkezett: 2019. 10. 16. 